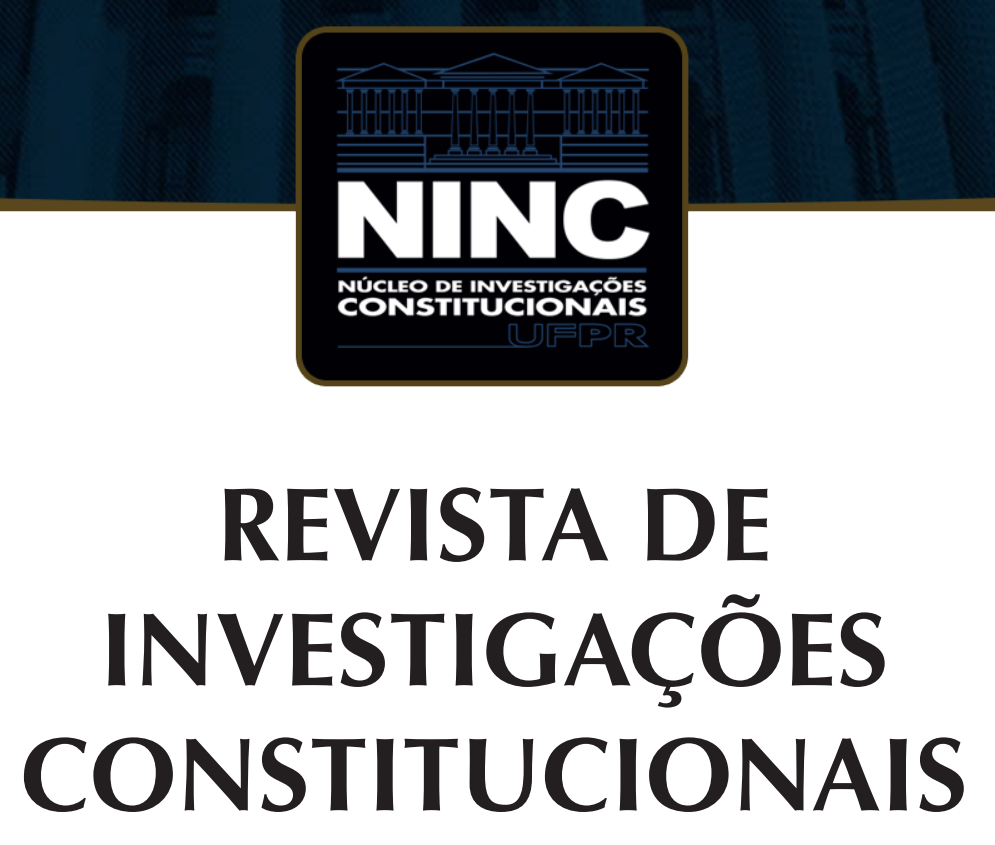

JOURNAL OF CONSTITUTIONAL RESEARCH

vol. 6 | n. 1 | janeiro/abril 2019 | ISSN 2359-5639 | Periodicidade quadrimestral Curitiba | Núcleo de Investigações Constitucionais da UFPR | www.ninc.com.br 


\section{A vitória pírrica da democracia constitucional}

\section{Constitutional democracy's pyrrhic victory}

\section{FAUSTO SANTOS DE MORAIS ${ }^{\mathrm{I},}$}

${ }^{\mathrm{I}}$ Faculdade Meridional - IMED (Brasil) faustosmorais@gmail.com

\section{FERNANDO GABRIEL GHIGGIII,**}

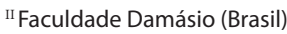
fernandoghiggi@gmail.com

Recebido/Received: 24.10.2017 / October 24 ${ }^{\text {th }}, 2017$ Aprovado/Approved: 15.01.2019 / January 15 th', 2019

\section{Resumo}

Na tradicional concepção de separação de poderes, o Legislativo assume o lócus das decisões políticas na sociedade por excelência. Não obstante, o controle judicial de constitucionalidade (judicial review) ascendeu de forma contumaz, sendo visto como aspecto essencial e indispensável às democracias constitucionais contemporâneas. No Brasil, o Supremo Tribunal Federal é expressamente consagrado guardião da Constituição, revelando-se detentor da última palavra nos diálogos institucionais travados com os demais poderes do Estado. Para muitos, a ascensão do Judiciário se trata de uma vitória à garantia dos direitos fundamentais. Para outros, trata-se tão somente de uma vitória pírrica: aparenta-se como uma conquista, mas seus prejuízos sobrepõem-se aos

\section{Abstract}

The traditional concept of separation of powers teaches that Legislative branch is the locus of political decisions in society by excellence. However, judicial review has ascended obstinately, being seen as an essential and needful aspect to contemporary constitutional democracies. In Brazil, Supremo Tribunal Federal is expressly consecrated guardian of the Constitution, getting the final say on institutional dialogues faced with other branches of the state. For many it is a victory for the guarantee of fundamental rights. For others, it is merely a Pyrrhic victory: it looks like an achievement, but its costs outweigh its gains. Adept of this premise, Jeremy Waldron develops an extensive criticism to judicial review of legislation, with foundation in his ideal conception of legislative institutions. Therefore, it is questioned: is

Como citar esse artigo/How to cite this article: MORAIS, Fausto Santos de; GHIGGI, Fernando Gabriel. A vitória pírrica da democracia constitucional. Revista de Investigações Constitucionais, Curitiba, vol. 6, n. 1, p. 135-164, jan./abr. 2019. DOI: 10.5380/ rinc.v6i1.56004.

"Docente da Escola de Direito e Programa de Pós-Graduação Estrito Senso - Mestrado em Direito, Faculdade Meridional - IMED (Passo Fundo-RS, Brasil). Doutor (2013) e Mestre (2010) em Direito Público pela Universidade do Vale do Rio dos Sinos - UNISINOS (São Leopoldo-RS, Brasil). Coordenador do grupo de pesquisa: Direitos Fundamentais, hermenêutica e proporcionalidade: crítica ao desenvolvimento prático-teórico do dever de proteção aos Direitos Fundamentais. Advogado. E-mail: faustosmorais@ gmail.com.

"* Pós-Graduado em Direito Constitucional pela Faculdade de Direito Prof. Damásio de Jesus - FDDJ (São Paulo-SP, Brasil). Graduado (2016) em Direito pela Faculdade Meridional - IMED (Passo Fundo-RS, Brasil). Integrante do grupo de pesquisa: Direitos Fundamentais, hermenêutica e proporcionalidade: crítica ao desenvolvimento prático-teórico do dever de proteção aos Direitos Fundamentais. Técnico Judiciário. E-mail: fernandoghiggi@gmail.com. 
ganhos. Adepto dessa premissa, o jusfilósofo Jeremy Waldron desenvolve vasta crítica ao controle jurisdicional de constitucionalidade, alicerçado em uma concepção ideal de instituições legislativas. Com efeito, indaga-se: é possível extrair contribuições ao contexto jurídico e político brasileiro pelo estudo da teoria de Waldron? Partindo-se dessa problemática, a presente pesquisa objetiva estudar e apresentar a teoria do citado autor, especulando-se, ao final, possíveis contribuições.

Palavras-chave: jurisdição constitucional; controle de constitucionalidade; diálogos institucionais; separação de poderes; Jeremy Waldron. it possible to extract contributions to Brazil's political and legal context from the study of Waldron's theory? Opening with this problematic, the present research aims to study and present Waldron's theory and to speculate possible contributions.

Keywords: judicial review; constitutional jurisdiction; institutional dialogues; separation of powers; Jeremy Waldron.

\section{SUMÁRIO}

1. Introdução; 2. A proposta teórica de Waldron: a ilegitimidade do judicial review; 2.1. Crítica ao controle judicial de constitucionalidade; 2.2. Tirania da maioria e admissão do controle judicial; 2.3. A defesa da democracia e das instituições legislativas; 3. Possíveis contribuições ao Brasil pela obra de Waldron; 3.1. Perspectivas iniciais ao âmbito legislativo; 3.2. Do legislativo à atual posição do judiciário no Brasil; 3.3. Aspectos intrínsecos ao âmbito judicial; 4 . Considerações finais; $\mathbf{5}$. Referências.

\section{INTRODUÇÃO}

No âmbito da teoria do direito e da filosofia política, situa-se o tema da legitimidade das decisões morais e políticas da sociedade, em face da assentada doutrina da separação dos poderes. Embora o Legislativo seja o lócus dessas decisões por excelência, persiste a legitimidade do controle judicial de constitucionalidade, com aporte na teoria dos direitos fundamentais, para revisão de deliberações legislativas a pretexto de reforçar a democracia.

Majoritariamente, vê-se essa atuação do Judiciário como aspecto positivo, uma vitória do constitucionalismo. Todavia, há visão contrária, no sentido de que os aspectos supostamente positivos dessa realidade são superados por decorrências negativas. Ou seja, se vista como uma vitória, seria, no máximo, uma vitória pírrica: comemorada de imediato, mas cuja perspectiva futura é preocupante, pois os prejuízos se sobrepõem aos ganhos.

Nesse viés, desenvolveu-se o presente estudo amparado pela teoria de Jeremy Waldron, jusfilósofo neozelandês, professor na New York University School of Law, nos EUA, adverso à revisão judicial da legislação e proponente de modelo ideal de política na relação entre Executivo, Legislativo e Judiciário. Com efeito, orientou-se pela seguinte problemática: é possível extrair contribuições ao contexto jurídico e político brasileiro, e às suas instituições, pelo estudo da teoria de Waldron?

Para tanto, o método fenomenológico hermenêutico sustenta o raciocínio investigativo à verificação da hipótese sustentada - de que há relevantes contribuições a 
serem extraídas da obra do citado autor. Diante disso, objetiva-se estudar e apresentar a teoria de Waldron, especulando-se as possíveis contribuições supracitadas.

Com efeito, a presente pesquisa será apresentada em duas seções. Primeiramente, apresentar-se-ão os principais aspectos teóricos da obra de Waldron acerca da ilegitimidade do controle de constitucionalidade e a ligação com seu modelo ideal de instituições legislativas. Em um segundo momento, elucidar-se-ão possíveis contribuições decorrentes do estudo da obra de Waldron aplicada ao atual contexto brasileiro.

Por fim, justifica-se a presente pesquisa pela constante necessidade de aferir a legitimidade do controle jurisdicional de constitucionalidade e a qualidade da tomada de decisões políticas e morais na sociedade. Ademais, sem debaterem-se adequadamente as questões vinculadas a essa temática não é possível uma visão clara acerca dos defeitos e qualidades das instituições centrais ao funcionamento e inter-relação entre os poderes do Estado - e em última análise, entre direito e política.

\section{A PROPOSTA TEÓRICA DE WALDRON: A ILEGITIMIDADE DO JU- DICIAL REVIEW}

Corriqueiramente, o povo decide assuntos controversos, mediante representantes eleitos e atuantes nas instituições do Poder Legislativo. Tomadas tais decisões, elas não devem passar por um "segundo turno de votação" ou consentimento pelos Tribunais, pois tal ação é desnecessária e carece de legitimidade política. Matérias como aborto, ações afirmativas, direitos em processos criminais, uniões homoafetivas, entre outras, são afetas aos cidadãos para decidir, e não à elite judicial'. Eis a premissa básica de Jeremy Waldron, aqui explorada.

Afinal, cidadãos levam a sério a ideia de serem regidos por direitos, e isso torna inevitável que surjam desacordos vigorosos e substanciais acerca do que efetivamente acarretam esses direitos ${ }^{2}$, especialmente em uma sociedade plural com diferentes ideologias. Por essa razão, assentam-se instituições legislativas, nas quais se reúnem as opiniões divergentes para resolução de tais controvérsias, em termos de razoável igualdade política. Logo, os desacordos não devem ser sanados por um corpo judiciário não eleito e não representativo, cujos membros discordam entre si sobre questões complexas tanto quanto os cidadãos e seus representantes ${ }^{3}$.

\footnotetext{
${ }^{1}$ WALDRON, Jeremy. The core case against judicial review. The Yale Law Journal, New Haven vol. 115, n. 6, p. 1346-1406, apr. 2006, p. 1348-1360.

${ }^{2}$ Dois cidadãos concordam que em dada sociedade é garantido o direito à vida e o direito à liberdade ou autonomia privada; ambos podem discordar, de boa-fé, sobre se deve ser garantido à mulher a escolha de realizar o aborto ou se deve ser garantido ao feto a proteção pela criminalização do aborto.

${ }^{3}$ WALDRON, Jeremy. The core case against judicial review. The Yale Law Journal, New Haven vol. 115, n. 6, p. 1346-1406, apr. 2006, p. 1360-1369.
} 
Waldron crê que o fato de comumente prevalecer a visão oposta à sua - ou seja, a aposta na revisão judicial - deve-se àquilo que ele denomina de "indignidade da legislação". Trata-se de circunstância que permeia o imaginário jurídico e social, pela qual a lei é vista como algo supérfluo, arbitrário e sem profundidade do ponto de vista da filosofia política e teoria do direito. Tal crença é fundada em uma espécie de realismo jurídico: a lei só se tornaria direito - ou um "direito digno" - quando é interpretada e administrada por tribunais ${ }^{4}$.

\subsection{Crítica ao controle judicial de constitucionalidade}

Nesse embate entre a visão ideal da legislação por Waldron e a descrença nas instituições democráticas, o jurista neozelandês propõe alguns argumentos elucidativos. Presumindo-se que nenhum procedimento será perfeito, aportam-se argumentos de resultado - acerca de qual instituição está menos propícia a violar direitos pelos resultados de suas decisões - e argumentos de procedimento - sobre qual instituição emprega o procedimento mais legítimo, passível de aceitação mesmo pelos grupos vencidos em questões controversas ${ }^{5}$.

Os argumentos elencados na categoria vinculada aos resultados afastam a primazia do Judiciário em decidir questões morais e a ideia de que o legislativo sempre tende a agir de modo irresponsável. Segundo o autor, trata-se de olhares superficiais e generalizantes ${ }^{6}$.

Há de se ter mente que mesmo diante da crença em verdades ou respostas corretas em matéria de direitos ou decisões morais, não há uma "teoria do erro" ou qualquer indicação objetiva de que a decisão foi ou não correta, subsistindo apenas visões diferentes. Nessa circunstância, é tão inadequado simplesmente "escolher" qual prevalecerá quanto denegrir arbitrariamente uma das visões sob o pretexto de a outra ser correta. E se juízes também discordam entre si, mesmo tendo em mente a busca pela resposta correta na matéria, o máximo que pode defender é o que ele acredita. Por isso, Waldron preza por uma análise do controle de constitucionalidade sob argumentos de justiça, equidade (fairness) e democracia?.

Dessa feita, talvez o principal argumento de resultado ${ }^{8}$ é a tendência das decisões judiciais a reduzirem as relevantes questões morais a "problemas de interpretação".

\footnotetext{
${ }^{4}$ WALDRON, Jeremy. A dignidade da legislação. Trad. de Luís Carlos Borges. São Paulo: Martins Fontes, 2003, p. 11-13. ${ }^{5}$ WALDRON, Jeremy. The core case against judicial review. The Yale Law Journal, New Haven vol. 115, n. 6, p. 1346-1406, apr. 2006, p. 1371-1375.

${ }^{6}$ WALDRON, Jeremy. Judges as moral reasoners. International Journal of Constitutional Law (I-CON), Oxford, vol. 7, n. 1, p. 2-24, 2009, p. 3-4.

${ }^{7}$ WALDRON, Jeremy. Law and disagreement. New York: Oxford University Press, 1999, p. 180-187.

${ }^{8}$ Outros argumentos de resultado: i) a falsa crença de que o raciocínio judicial é orientado a casos particulares: nas altas cortes, não mais subsiste a concretude, resumindo-se a disputas abstratas sobre o direito em tese;
} 
Cientes de seu déficit de legitimidade, juízes se agarram a autorizações para decidir: um "céu textual" da Constituição. Essa, no entanto, não resolve a matéria, prevendo tão somente dispositivos vagos em seu rol de direitos e garantias. Não se debate o mérito da questão, mas teorias ou interpretações divergentes. O Tribunal se vincularia ao que outros já disseram ou decidiram?.

Por outro lado, instituições democráticas analisam a matéria diretamente no seu mérito, não restringidas ou distraídas por texto, doutrina ou precedente. Problemas de direitos individuais são questões práticas que refletem o momento político da comunidade. São questões divisoras de água (watershed). Portanto, é relevante o debate na sua origem (freshly). Assim, apostar no judicial review acaba por reduzir essas matérias relevantes a meros "problemas de interpretação" ${ }^{10}$.

Já quanto às razões de procedimento, Waldron explica que se trata de convencer aqueles que discordam do mérito ou resultado da decisão que, ainda assim, ela foi tomada de modo justo. Em suma, responde-se: "por que essas pessoas decidiram?"; e "por que se deu mais peso a este e não ao outro entendimento?" 11.

Para o autor, o legislativo leva vantagem nesse aspecto pelo seu procedimento decisório: o voto majoritário. Primeiramente, é um modo de atender à igualdade política entre as opiniões, dando-as exatamente o mesmo peso, além de garantir o maior poder e a maior possibilidade de expressão (say) possível - reforçado pela existência de duas decisões majoritárias, uma nas eleições e outra entre os representantes eleitos ${ }^{12}$. Isto é, votar não seria apenas uma contagem numérica ${ }^{13}$.

Por outro lado, o Judiciário, embora também tome decisões por maioria de votos, não possui o mesmo embasamento moral de igualdade política. Seus membros votam por serem todos igualmente experts no direito. Mas, também discordam entre si,

ii) a inexatidão de defender a primazia judicial por suas decisões serem fundamentadas: o Legislativo possui seu âmbito de fundamentação (Diários, Hansard ou Congressional Records), mas os juristas são treinados para estudar a fundamentação judicial e não legislativa; iii) alega-se que o Legislativo é influenciado por interesses sectários, econômicos, pessoais, etc., mas, quanto isso, ambas as instituições podem ser afetadas, tratando-se de circunstância excepcional a admissão do judicial review apenas diante de "patologias legislativas", pois o mero funcionamento de modo rude ou imperfeito já garantiria uma gama representativa consideravelmente maior do que a existente nos Tribunais. WALDRON, Jeremy. The core case against judicial review. The Yale Law Journal, New Haven vol. 115, n. 6, p. 1346-1406, apr. 2006, p. 1376-1386.

${ }^{9}$ WALDRON, Jeremy. The core case against judicial review. The Yale Law Journal, New Haven vol. 115, n. 6, p. 1346-1406, apr. 2006, p. 1381-1384.

${ }^{10}$ WALDRON, Jeremy. Judges as moral reasoners. International Journal of Constitutional Law (I-CON), Oxford, vol. 7, n. 1, p. 2-24, 2009, p. 19-23.

${ }^{11}$ WALDRON, Jeremy. The core case against judicial review. The Yale Law Journal, New Haven vol. 115, n. 6, p. 1346-1406, apr. 2006, p. 1386-1387. Isto é, além de resolver a disputa, o procedimento decisório deve "reconciliar" a parte vencida, fazendo-a aceitar a decisão em razão do processo pelo qual foi tomada. WALDRON, Jeremy. Political political theory: essays on institutions. Cambridge: Harvard Univeristy Press, 2016, p. 255.

${ }^{12}$ WALDRON, Jeremy. The core case against judicial review. The Yale Law Journal, New Haven vol. 115, n. 6, p. 1346-1406, apr. 2006, p. 1387-1389.

${ }^{13}$ WALDRON, Jeremy. Law and disagreement. New York: Oxford University Press, 1999, p. 88-91. 
e não há como convencer um cidadão, defensor da opinião vencida, que o juiz com o qual ele concorda seja "menos expert" do que o juiz vencedor ${ }^{14}$.

Ademais, a única fonte de legitimidade democrática seria a nomeação pelo Presidente com sabatina pelo órgão legislativo, mas além de não atender à mesma gama de diversidade e representatividade das instituições legislativas, vincular os juízes a credenciais políticas e democráticas acaba mitigando o argumento comum em favor do judicial review: de que os Tribunais são um âmbito independente e distintivo de tomada de decisões se comparados ao meio político e eleitoral ${ }^{15}$.

Questões de legitimidade levantadas por argumentos de procedimento são eminentemente comparativas. Responder ao cidadão anteriormente citado sobre o porquê da decisão ser tomada do modo que foi não encontra a mesma facilidade no Judiciário se comparado ao Legislativo. Logo, as razões de procedimento colocam em cheque as instituições judiciais ao falharem perante reclames de equidade (fairness) do princípio de igualdade política. Tal falha poderia ser sanada por uma defesa quanto às razões de mérito. Se uma instituição fosse claramente superior em decidir sobre quais direitos as pessoas têm, isso pesaria a favor dela. Todavia, não é o caso: as razões de resultado são inconclusivas, pois cidadãos e juízes discordam e argumentam levando direitos a sério ou são até favoráveis ao Legislativo ${ }^{16}$.

Por fim, contesta-se a crença de que o Judiciário está apenas fazendo cumprir comprometimentos prévios que a sociedade assumiu na Constituição. Afinal, se tal documento, como se disse, está longe de resolver de fato a matéria por si, não se admite que um pequeno grupo de juízes dite qual o comprometimento assumido pela sociedade, nem se assume que efetivamente a sociedade tenha se vinculado a alguma visão ou interpretação particular, exarada conforme a opinião do juiz acerca de determinado direito nela previsto ${ }^{17}$.

\footnotetext{
${ }^{14}$ WALDRON, Jeremy. Political political theory: essays on institutions. Cambridge: Harvard Univeristy Press, 2016, p. 257-269.

${ }^{15}$ WALDRON, Jeremy. The core case against judicial review. The Yale Law Journal, New Haven vol. 115, n. 6, p. 1346-1406, apr. 2006, p. 1391 e 1394.

${ }^{16}$ WALDRON, Jeremy. The core case against judicial review. The Yale Law Journal, New Haven vol. 115, n. 6, p. 1346-1406, apr. 2006, p. 1389-1393. O Legislativo faz um juízo publico sobre os direitos, e fixa-o como base para coordenação social. Não há a necessidade de uma instituição adicional para testar se as leis promulgadas estão de acordo com uma espécie de "direito natural", pois é basicamente o que os legisladores já fizeram. Os membros da sociedade discordam, e o legislativo faz o julgamento (adjudication) dessa controversa. WALDRON, Jeremy. Law and disagreement. New York: Oxford University Press, 1999, p. 309.

${ }^{17}$ WALDRON, Jeremy. The core case against judicial review. The Yale Law Journal, New Haven vol. 115, n. 6, p. 1346-1406, apr. 2006, p. 1393-1394. Cita-se analogia com a odisseia de Ulysses, o qual pediu para amarrarem-no ao mastro do navio e não soltá-lo para que não caísse na tentação das sereias, devendo ser apertadas ainda mais as cordas caso pedisse para soltá-las. Defensores do judicial reviewt entariam aplicar essa lógica de reforçar ainda mais o "comprometimento prévio" às restrições (constitucionais) impostas, mas Waldron desconstrói o argumento com base no fato de que as determinações da Constituição não detém essa mesma lógica de certeza e causalidade da história de Ulysses, pois operam mediante baixa previsibilidade, com desacordos e fortes controversas sobre o comprometimento exato. Além disso, não são restrições impostas pelo próprio destinatário, estando os
} 


\subsection{Tirania da maioria e admissão do controle judicial}

Com tudo isso em mente, afasta-se o principal receio em relação às instituições democráticas: a tirania da maioria. Se as pessoas discordam acerca de como resolver disputas sobre direitos e se qualquer procedimento decisório poderá tomar decisões incorretas, a tirania é aspecto inevitável. Trata-se, novamente, de questão comparativa, e o Poder Legislativo traz uma qualidade ímpar na determinação final em questões sobre direitos: é o único que não excluiria, tiranicamente, certas pessoas de participarem como iguais na tomada de decisão ${ }^{18}$.

Waldron quer diferenciar meros desacordos de efetiva tirania. Mesmo entre juízes não se escapa de minorias e maiorias - discordando vigorosamente - e nem por isso se diz que o grupo de juízes minoritários sofreu de "tirania" 19. Tal constatação é importante para afastar o argumento da tirania pela simples incompatibilidade da votação majoritária com "levar a sério" questões de princípio. O autor ironiza com o fato de que, no final das contas, mesmo juízes não têm nada a fazer além de "contar cabeças". Igualmente, pode-se pensar de modo mais aberto - e tolerante - na existência de desacordos razoáveis: juízes são experts em direito constitucional e discordam tanto quanto cidadãos comuns. Por isso, não é necessário abandonar as convicções assumidas, mas é preciso reconhecer que a visão do oponente não é necessariamente intolerante, corrupta ou deturpada ${ }^{20}$.

cidadãos de hoje incumbidos de definir se "foi esse o comprometimento prévio" assumido pelo constituinte. O desacordo perpassa todos os níveis: entre os que escreveram a Constituição, entre os Legisladores que resolvem a matéria e entre os juízes que abordaram a causa no sistema do judicial review, não ostentando os últimos, portanto, maior legitimidade para decidir. WALDRON, Jeremy. Law and disagreement. New York: Oxford University Press, 1999, p. 258-280.

${ }^{18}$ WALDRON, Jeremy. The core case against judicial review. The Yale Law Journal, New Haven vol. 115, n. 6, p. 1346-1406, apr. 2006, p. 1395-1396 e WALDRON, Jeremy. Law and disagreement. New York: Oxford University Press, 1999, p. 299. Waldron coloca a seguinte proposição: todos os procedimentos de decisão política tem a mesma possibilidade de alcançar decisões equivocadas, mas em geral possuem um defeito que a decisão majoritária não tem: "não permitem que todos os cidadãos da sociedade opinem e votem em um procedimento decisório final; ao invés disso, dão a decisão final sobre os direitos de milhões para as opiniões e votos de alguns poucos". WALDRON, Jeremy. Law and disagreement. New York: Oxford University Press, 1999, p. 299.

${ }^{19}$ WALDRON, Jeremy. Political political theory: essays on institutions. Cambridge: Harvard Univeristy Press, 2016, p. 269-271. Por isso, em releitura ao constitucionalismo, Waldron diz que o controle judicial pode parecer o mero cumprimento da tarefa interpretativa da Corte, mas um olhar atento verá que relevantes decisões sobre a forma e o caráter da Constituição foram tomadas por um órgão que, pela soberania popular, não tem mais direito (has no greater right) do que poderes eleitos. A soberania popular é citada como legitimação ao juicial review diante das restrições impostas "pelo próprio povo" na Constituição num passado remoto, mas não é levada em conta como argumento contra a autoridade da Corte, pelo qual as formulações abstratas demandariam respostas também "pelo próprio povo" de hoje, por decisão majoritária, diante do desacordo existente. WALDRON, Jeremy. Political political theory: essays on institutions. Cambridge: Harvard Univeristy Press, 2016, p. 39-43.

${ }^{20}$ WALDRON, Jeremy. Political political theory: essays on institutions. Cambridge: Harvard Univeristy Press, 2016, p. 270. Ainda assim, a ideia de que tudo que seja objeto de desacordos razoáveis está ao alcance (up for grabs) de decisões democráticas parece "perturbadora". Mas, dois pontos são importantes. Primeiramente, não significa curvar-se a decisões apressadas, impetuosas, instabilidade e constantes alterações - o processo legislativo deve ser complexo e trabalhoso, com mecanismos que impedem a revisão de questões recentemente 
Com essa premissa, Waldron explica que as situações realmente preocupantes são aquelas em que se verifica um alinhamento entre uma minoria decisória e o grupo minoritário afetado pela decisão ${ }^{21}$. Por isso, reconhece que em algumas ocasiões a revisão judicial pode sobressair-se às suas consequências de "ofuscação e ineficácia do voto" (disenfranchisement) e à supremacia do legislativo. $\mathrm{O}$ autor não defende a inadequação absoluta do controle de constitucionalidade, mas apenas em sociedades democráticas cujo problema principal não seja suas instituições, e sim o desacordo sobre direitos. A prática não seria o paradigma ideal do respeito aos direitos, e nem elemento desejável às democracias constitucionais modernas ${ }^{22}$.

Não obstante, o autor delimita apenas de modo vago aquilo que ele chama de casos "não-paradigma" (non-core cases). Alude a circunstâncias dependentes de verificação empírica, relativas à cultura política ou um legislativo patológico e disfuncional, com legados de corrupção, racismo e outras formas de preconceito.

Waldron reconhece a defesa à revisão judicial quando se vislumbram minorias segredadas sem representatividade, que não têm compartilhados com a comunidade seus interesses e não veem a possibilidade de promovê-los - efetivamente separadas e isoladas (discrete and insular). Coloca-se em cheque a capacidade do processo político-legislativo de protegê-las, demandando-se instituições não eleitas para garantir os direitos da minoria e reparar o sistema, propiciando a devida representação ${ }^{23}$. Em

votadas. Outrossim, o respeito pelas opiniões alheias impõe que indivíduos singulares não possuam controle sobre os resultados substanciais e políticos que sua própria consciência e princípios lhe ditam. Dizer que as questões estão em aberto (up for grabs) não significa uma política egoísta de troca de favores (selfish pork-barreling). Se for imputada tal constatação empírica, deve-se fazer de modo especial, com alusão a algo que vá além do objeto dos desacordos sobre questões complexas. WALDRON, Jeremy. Law and disagreement. New York: Oxford University Press, 1999, p. 303-304.

${ }^{21}$ WALDRON, Jeremy. The core case against judicial review. The Yale Law Journal, New Haven vol. 115, n. 6, p. 1346-1406, apr. 2006, p. 1396-1398.

${ }^{22}$ WALDRON, Jeremy. The core case against judicial review. The Yale Law Journal, New Haven vol. 115, n. 6, p. 1346-1406, apr. 2006, p. 1406.

${ }^{23}$ WALDRON, Jeremy. The core case against judicial review. The Yale Law Journal, New Haven vol. 115, n. 6, p. 1346-1406, apr. 2006, p. 1403-1404. Waldron cita o texto do juiz Harlan Stone, membro da Suprema Corte dos Estados Unidos, aludindo à nota de rodapé número quatro da decisão do caso United States v. Carolene Products (1938), cuja decisão deu-se no sentido de não derrubar uma lei que proibia a mistura de substâncias ao leite para alterar suas características, alegando-se a "presunção de constitucionalidade" existente dentro da margem de apreciação do Poder Legislativo. A referida nota definiu situações que mitigariam a "presunção de constitucionalidade" da legislação, por demandarem análise mais rigorosa quanto à imposição restrições à atividade política, a citar, casos de discriminações contra "minorias isoladas (insular) e separadas (discretes)". Além desses casos mencionados por Waldron, fala-se também das situações de afronta direta (facial, literal) à Constituição, e; tentativa de distorcer, obstruir ou fraudar processos políticos. Esse conjunto de considerações levantados na decisão serviu de base, também, a outra teoria restrita quanto à revisão judicial da legislação proposta por John Hart Ely, autor cuja teoria contribuiu às concessões de Waldron ao judicial review. WALDRON, Jeremy. The core case against judicial review. The Yale Law Journal, New Haven vol. 115, n. 6, p. 1346-1406, apr. 2006, p. 1403. Cf. ELY, John Hart. Democracia e desconfiança: uma teoria do controle judicial de constitucionalidade. Trad. de Juliana Lemos. São Paulo: Martins Fontes, 2010, p. 100-102. 
situações dessa natureza, o judicial review seria um meio adicional de participação pela desobstrução das vias políticas ${ }^{24}$.

O autor neozelandês utiliza-se, em parte, da teoria de John Hart Ely, autor norte americano e defensor de um controle procedimental, para elucidar casos em que se admitiria a intervenção judicial. Ely arguia que o controle judicial poderia ocorrer diante do mau funcionamento dos procedimentos democráticos. Em suma, seriam duas hipóteses: (i) na obstrução de canais de mudança política pelos incluídos no sistema, de forma que os excluídos não tenham perspectiva de mudança; e (ii) quando não há a exclusão de fato do voto e participação, mas representantes majoritários, por hostilidade ou preconceito, sistematicamente impõem desvantagens à minoria, negando proteções fornecidas sem ressalvas a outros grupos ${ }^{25}$.

Ainda assim, Waldron é mais restrito do que Ely na admissão do judicial review. Por exemplo, enquanto Ely admite que os homossexuais sejam um grupo que merecem a intervenção do controle judicial, Waldron nega que seja o caso ${ }^{26}$. Ademais, para o neozelandês questões procedimentais também originam desacordos profundos e de boa-fé, desde constitucionalistas a cientistas políticos - em geral, são passíveis de decisão pelas instituições democráticas. Cidadãos, parlamentares e juízes discordam igualmente entre si, havendo um "contínuo trabalho de aprimoramento" ${ }^{27}$. As circunstâncias sempre são tais que é impossível sustentar coerentemente a ilegitimidade procedimental do sistema, pois a alegação de ilegitimidade pode ser feita tanto por defensores quanto opositores de determinado direito procedimental, seja qual for o resultado da decisão majoritária ${ }^{28}$.

Com efeito, as situações de controle judicial admitidas por Waldron são restritas a uma combinação entre (i) a efetiva desobstrução de canais de mudança política diante de disfunções e patologias legislativas ou culturas políticas de corrupção - ou uma

\footnotetext{
${ }^{24}$ WALDRON, Jeremy. The core case against judicial review. The Yale Law Journal, vol. 115, n. 06, p. 1346-1406, 2006, p. 1395.

${ }^{25}$ Cf. ELY, John Hart. Democracia e desconfiança: uma teoria do controle judicial de constitucionalidade. Trad. de Juliana Lemos. São Paulo: Martins Fontes, 2010, p.137.

${ }^{26} \mathrm{Cf}$. WALDRON, Jeremy. The core case against judicial review. The Yale Law Journal, New Haven vol. 115, $\mathrm{n}$. 6, p. 1346-1406, apr. 2006, p. 1349-1350; e WALDRON, Jeremy. Parliamentary recklessness: why we need to legislate more carefully. Maxim Institute. Auckland: New Zealand, 2008, p. 11-13.

${ }^{27}$ WALDRON, Jeremy. Law and disagreement. New York: Oxford University Press, 1999, p. 277-281.

${ }^{28}$ WALDRON, Jeremy. Law and disagreement. New York: Oxford University Press, 1999, p. 283-302. O autor neozelandês exemplifica da seguinte forma: (i) na ausência do direito procedimental "x", se uma decisão majoritária que mantenha a ausência desse direito for taxada de ilegítima, o mesmo poderia ser alegado pelos opositores de tal direito se a votação fosse no sentido de conferir o direito " $x$ ", pois o grupo que agora seria vencedor não poderia sustentar que a ausência de tal direito deslegitima apenas as decisões contrárias a si (ambas ocorreriam na mesma circunstância de alegada "ilegitimidade"); (ii) se há discussão sobre ser adequado ou não um direito " $y$ ", em um contexto no qual é atualmente garantido tal direito, pode-se votar e diminuir ou revogar o direito " $y$ ", e isso não pode ser taxado de ilegítimo por seus defensores, pois eles estavam nas condições ideais para decidir - e embora as decisões subsequentes possam por eles serem chamadas de ilegítimas, o mesmo ocorria sistematicamente até o momento da decisão, do ponto de vista do grupo contrário. WALDRON, Jeremy. Law and disagreement. New York: Oxford University Press, 1999, p. 298-301.
} 
explícita violação da igualdade política ou sufrágio universal (ao excluir um grupo da participação) e (ii) minorias isoladas e segregadas que fossem vítimas de preconceito. $\mathrm{O}$ isolamento, para Waldron, não é apenas no aspecto político, mas isolada da comunidade em si, sem perspectiva de coligar-se pelo compartilhamento de interesses e promoção dos seus próprios. A ideia do preconceito busca refletir uma verdadeira antipatia inconsciente e impregnada, e não o mero desacordo razoável acerca de determinado direito. Um preconceito difundido é incompatível com as premissas acerca do comprometimento comum e desacordos de boa-fé, pela indiferença ou hostilidade em dissensos irracionais perante direitos de minorias ${ }^{29}$.

Enfim, seriam situações realmente extremas, endêmicas e sistemáticas que excluam certo grupo da participação democrática. Ou, ainda, repetidas desvantagens por um processo legislativo que, de alguma forma, silencia as demandas do grupo minoritário, ao longo de uma série de rodadas políticas ${ }^{30}$, sem que membros de outros grupos simpatizem ou se conciliem com seus interesses para promovê-los em conjunto.

Deve-se apenas ter cuidado com argumentos excessivamente depreciativos da maioria, bem como da crença cega na elite judicial. Quando se argui que a maioria simplesmente despreza as necessidades da minoria, não se contamina apenas as decisões majoritárias, mas todos os procedimentos vinculados às decisões políticas. Por exemplo, a minoria que tenha tamanha desconfiança da maioria suscitará dúvidas e equívocos sobre a seleção e nomeação de magistrados, bem como sobre a ideologia de suas decisões ${ }^{31}$.

Com isso, Waldron aduz que argumentos sobre direitos - das minorias - não devem ser vistos como razão absoluta em favor da revisão judicial. Não há argumento definitivo em prol do controle de constitucionalidade. Por isso, ao defendê-lo, deve-se visar às situações de patologias e disfunções legislativas, legados de racismo e preconceitos endêmicos. E dirá Waldron: deve-se fazê-lo com humildade e vergonha das circunstâncias que demandam sua evocação, ao invés celebrar e proclamar a intervenção

\footnotetext{
${ }^{29}$ WALDRON, Jeremy. The core case against judicial review. The Yale Law Journal, New Haven vol. 115, n. 6, p. 1346-1406, apr. 2006, p. 1404.

${ }^{30}$ Quando da conceituação da accountability democrática e judicial, Waldron expõe que "às vezes, um conjunto do eleitorado (principals) - um subconjunto do povo - conspiram contra uma minoria, em conluio com aqueles que devem ser os representantes (agents). Deve existir um modo de prevenir isso, e a accountability forense das cortes pode ser a resposta. Mas, isso não faz da accountability forense uma forma de accountability democrática". WALDRON, Jeremy. Political political theory: essays on institutions. Cambridge: Harvard Univeristy Press, 2016, p. 193.

${ }^{31}$ WALDRON, Jeremy. Law and disagreement. New York: Oxford University Press, 1999, p. 299. Explica o autor que é necessário averiguar se as maiorias judiciais não estão infectadas com o preconceito que se visa erradicar. Se algum resquício de respeito por direitos existe entre as elites políticas, então a autoridade final deve permanecer, de fato, com os juízes. Todavia, se há simpatia pelas minorias entre as "pessoas comuns", então as instituições eletivas providenciam meios para canalizar o suporte popular dentro do Legislativo, o que inexiste no Judiciário. WALDRON, Jeremy. The core case against judicial review. The Yale Law Journal, New Haven vol. 115 , n. 6 , p. 1346-1406, apr. 2006, p. 1405
} 
judicial como se fosse uma vitória, ou o ápice do respeito pelos direitos nas democracias constitucionais $^{32}$. Uma vitória, mantida tal conjuntura, seria apenas uma vitória pírrica ${ }^{33}$ para a democracia constitucional.

\subsection{A defesa da democracia e das instituições legislativas}

Um sentimento de vergonha parece estar longe da atual visão sobre decisões acerca da inconstitucionalidade de leis apreciadas. Todavia, isso se fundamenta na premissa básica de Waldron por trás da crítica ao judicial review: a democracia é uma conquista positiva. Por isso, se a intervenção judicial depende de disfunções representativas, é sinal de enorme perda ao ordenamento constitucional-democrático.

Há um histórico de lutas e celebradas conquistas em prol da democracia, especialmente do direito ao voto universal - contra restrições diretas ou indiretas à participação política por motivos de classe social ou montante patrimonial (pobres), de gênero (mulheres), ou raciais (negros). Tais lutas foram (e são) pelo direito à igual participação na decisão sobre questões de direitos, de políticas e de princípios ${ }^{34}$. A participação, dirá Waldron, é o direito dos direitos ${ }^{35}$.

Torna-se incongruente celebrar essas lutas e vitórias e, ao mesmo tempo, ter uma visão unicamente pessimista do sistema democrático. De fato, alegações de que políticas eleitorais e legislativas se pautam em assuntos de interesses pessoais e que eleitores e representantes nunca pensam além do melhor para si são problemas empíricos, por vezes aumentados exageradamente. Se esse "cinismo" for levado a diante, pode-se insistir que filósofos também escrevem por puro interesse particular, assim como

\footnotetext{
${ }^{32}$ WALDRON, Jeremy. The core case against judicial review. The Yale Law Journal, New Haven vol. 115, n. 6, p. 1346-1406, apr. 2006, p. 1406.

${ }^{33}$ Karl Loewenstein fala em vitória pírrica da democracia constitucional relativamente à relevância - ainda que muitas vezes simbólica - adquirida pelas cartas escritas de direitos, no contexto constitucionalismo, bem como pelo fato de que nenhum sistema político, ainda que autoritário, vê-se capaz de rechaçar explicitamente a ideologia democrática de que todo poder emana do povo e apenas será legítimo seu exercício em nome deste. Ainda assim, a democracia constitucional passa por um estágio de crise, principalmente pela falta de normatividade dos textos constitucionais e pela indiferença dos seus próprios destinatários - algo que o autor chama de "atrofia da consciência constitucional". Essa circunstância se fortalece pelo fato de que a constituição se distancia da população e aproxima-se do jogo de interesses dos detentores do poder de fato. LOEWENSTEIN, Karl. Teoría de la constitutión. 2. ed. Barcelona: Ariel, 1976, p. 213-215 e p. 222-231. Nesse sentido, Waldron apresenta uma postura crítica - ou visão cética - em relação ao constitucionalismo. Segundo o jurista neozelandês, há foco demasiado em restrições à atuação legislativa, sem conceber adequadamente a soberania popular e empoderar (empower) o povo na participação das decisões, incumbência ínsita à Constituição enquanto base da deliberação política. Isto é, há uma tarefa constitucional de estruturar instituições e procedimentos que viabilizem a persecução de ideais e projetos pela população, levando a sério a integridade do processo de criação legislativa e tomada de decisões políticas, e não apenas focado na "limitação". É como "a Constituição pode tornar possível, afirmativamente, aquilo que de outro modo seria a perigosa política das ruas". WALDRON, Jeremy. Political political theory: essays on institutions. Cambridge: Harvard Univeristy Press, 2016, p. 34-36.

${ }^{34}$ WALDRON, Jeremy. Law and disagreement. New York: Oxford University Press, 1999, p. 249-255.

${ }^{35}$ WALDRON, Jeremy. Law and disagreement. New York: Oxford University Press, 1999, p. 251-254.
} 
o mesmo pode ser dito sobre a atuação de juízes, sobre quem escreveu a Constituição, e até sobre si próprio. Seguir nisso impossibilita desenhar conclusões sobre instituições ou sobre política. Portanto, quer-se atribuir a possibilidade de que cidadãos e seus representantes, ao menos em parte do tempo, pensam com zelo, boa-fé e seriedade em questões de princípios, justiça e direitos ${ }^{36}$.

Daí surge a importante conclusão: existem situações que demandam intervenção judicial, mas isso não significa que se devem deixar de lado as causas que exigiram tal intervenção. Isto é, admitir que dada nação necessite do controle judicial não pode servir de base para um descaso em relação à situação das instituições legislativas, sem uma busca por constantes avanços, correções e aprimoramentos. Não se pode permitir que a atuação do Judiciário gere certa "zona de conforto" no atual quadro das instituições democráticas, dificultando sua reforma e o desenvolvimento de uma cultura responsável, diante da constante atuação judicial como constante backup ${ }^{37}$. Como referido acima, celebrar vitórias esparsas, se mantidas as circunstâncias políticas, resume-se a uma vitória pírrica à democracia.

Isso se pauta em outra importante assunção feita por Waldron: legislar pode ser visto de duas formas. A primeira delas, mais rudimentar, é um "procedimentalismo estúpido ${ }^{38}$, formado por um conjunto de regras arbitrariamente estabelecidas, de tal forma que apenas deve ser seguido às cegas o rito legislativo, apostando-se no Judiciário como forma de revisar decisões com as quais se discorde ${ }^{39}$. Notoriamente, essa não é a concepção do citado autor.

Em contraposição, Waldron defende uma visão pautada na integridade legislativa e dignidade da legislação. Ambas classificações formam um conceito que pode ser sintetizado na observância de três premissas básicas. Primeiramente, admite-se que o processo legislativo não se resume ao conjunto de regras, sendo pautado por princípios subjacentes, a citar: transparência, dever de cuidado (duty of care) com interesses e liberdades em jogo, representação, respeito pelos desacordos e oposição leal (loyal opposition), deliberação responsiva, formalidade legislativa e igualdade política (respaldada pelo voto majoritário) ${ }^{40}$.

\footnotetext{
${ }^{36}$ WALDRON, Jeremy. Law and disagreement. New York: Oxford University Press, 1999, p. 14-15 e p. 230.

${ }^{37}$ WALDRON, Jeremy. The core case against judicial review. The Yale Law Journal, New Haven vol. 115, n. 6, p. 1346-1406, apr. 2006, p. 1403.

${ }^{38}$ WALDRON, Jeremy. Political political theory: essays on institutions. Cambridge: Harvard Univeristy Press, 2016, p. 166.

${ }^{39}$ WALDRON, Jeremy. Legislating with Integrity. Fordham Law Review, New York, vol. 72, n. 2 p. 373-394, 2003, p. 374-377. Para explicar essa visão, o jurista lança frase dita, em tese, por OttoVon Bismarck "[...] uma pessoa com afeição pela lei, assim como uma pessoa com afeição por salsichas, não deve investigar muito de perto os processos pelos quais elas são feitas", para referir o desgosto ao tomar ciência de como se dá sua criação. WALDRON, Jeremy. Legislating with Integrity. Fordham Law Review, New York, vol. 72, n. 2 p. 373-394, 2003, p. 374. ${ }^{40}$ WALDRON, Jeremy. Political political theory: essays on institutions. Cambridge: Harvard Univeristy Press, 2016, p. 153-164.
} 
A função desses princípios vai desde a explicitação da finalidade das regras legislativas, distinção entre atuação íntegra e não íntegra, até a avaliação crítica do sistema. Pode-se fazer um paralelo com regras procedimentais de um julgamento criminal: não são um fim em si mesmo, pois se orientam a princípios subjacentes - respeito pelo indivíduo, busca da verdade, presunção de inocência e não autoincriminação. Quando se estrutura o processo judicial, têm-se em mente esses princípios para avaliar as regras e advogar por mudanças, além de orientar o comportamento dos participantes. O mesmo deve ocorrer no Legislativo ${ }^{41}$.

Como segundo pilar, emerge o caráter formal e deliberativo na instituição representativa de uma gama de interesses de toda a sociedade. Não se trata apenas de reunir e votar, mas efetivamente discutir as leis e medidas em pauta. O corpo legislativo é formado por pessoas diferentes em seu passado, crenças, experiências de vida e visão sobre justiça, política e direitos. Pela grande diversidade de perspectivas e contribuições advindas em decorrência do grande número de indivíduos, alcançam-se decisões melhores do que qualquer membro alcançaria sozinho (uma inteligência coletiva) ${ }^{42}$.

Isso é extraído por Waldron da obra de Aristóteles, no debate sobre a população em geral ou "os poucos melhores" estarem no poder. Ante o caráter multifacetado das decisões políticas e questões de princípio, nenhuma pessoa detém todo o conhecimento necessário, mas cada um terá sobre uma parte. Assim, ainda que se compare com "o mais sábio e capaz", o povo, na consideração coletiva, pode tomar decisões melhores, em face do conhecimento e experiência de vida de cada pessoa, enquanto "o(s) melhor(es)" possuem apenas seus recursos e experiências individuais ${ }^{43}$. Trata-se da sabedoria da multidão (wisdom of the multitude) ${ }^{44}$.

\footnotetext{
${ }^{41}$ WALDRON, Jeremy. Political political theory: essays on institutions. Cambridge: Harvard Univeristy Press, 2016, p. 165-166; e WALDRON, Jeremy. Legislating with Integrity. Fordham Law Review, New York, vol. 72, n. 2 p. 373-394, 2003.

${ }^{42}$ WALDRON, Jeremy. Law and disagreement. New York: Oxford University Press, 1999, p. 69-74.

${ }^{43}$ WALDRON, Jeremy. Law and disagreement. New York: Oxford University Press, 1999, p. 72 e 136-142. O autor também aborda a possibilidade de utilizar o teorema do júri de Condorcet, que formulou uma construção aritmética segundo a qual a atuação em grupo, com pessoas razoavelmente competentes (no teorema, mais de 0.5 de chance de acerto), terá mais chance de dar a resposta correta do que qualquer um dos membros individualmente. Todavia, Waldron diz que esse não pode ser o fundamento, pois, no cálculo de Condorcet, conforme o grupo aumenta de tamanho, após certo ponto, a competência individual tende a reduzir gradativamente, pendendo contrariamente à assembleia em grandes números. WALDRON, Jeremy. Law and disagreement. New York: Oxford University Press, 1999, p. 51-52, e WALDRON, Jeremy. Political political theory: essays on institutions. Cambridge: Harvard Univeristy Press, 2016, p. 131-132 e 368.

${ }^{44}$ WALDRON, Jeremy. A dignidade da legislação. Trad. de Luís Carlos Borges. São Paulo: Martins Fontes, 2003, p. 113132. Em face disso, o direito à participação é semelhante ao direito à propriedade: inicialmente, pertencente ao indivíduo - sua propriedade privada -, mas, não é exercido apenas para seu propósito particular, pois possui uma fundamentação racional coletiva (função social), de contribuir para a qualidade do julgamento, interagindo deliberativamente até o voto em assembleia. WALDRON, Jeremy. A dignidade da legislação. Trad. de Luís Carlos Borges. São Paulo: Martins Fontes, 2003, p. 139.
} 
Como último pilar da integridade e dignidade surge a independência institucional em relação ao Executivo. Assim, garante-se que o legislativo seja um local de debate genuíno, não focado apenas em cumprir a agenda daquele poder. Um sistema bicameral seriam um início apto a permitir que ao menos uma das casas funcione de tal modo ${ }^{45}$.

Com a combinação desses elementos, a legislação poderia (e deveria) assumir o centro das decisões políticas na sociedade. Dessa feita, assentada a crítica de Waldron, indaga-se: é possível que sua teoria irradie sobre o ordenamento jurídico brasileiro, fortemente centrado no Poder Judiciário, e forneça aportes a possíveis contribuições? A seção seguinte se destina a demonstrar que a resposta é afirmativa, elencando sete aspectos que podem sofrer influência pela obra do autor neozelandês.

\section{POSSÍVEIS CONTRIBUIÇÕES AO BRASIL PELA OBRA DE WALDRON}

Da mesma forma que a base teórica de Waldron sobre o Poder Legislativo e o judicial review se mostram interligadas, também as contribuições decorrentes da obra do autor irradiam sobre o Legislativo, o Executivo e o Judiciário. Expor-se-ão, no presente capítulo, sete possíveis contribuições que merecem maior atenção, sem, evidentemente, precluir a possibilidade de outras tão ou mais importantes do que as aqui elencadas.

\subsection{Perspectivas iniciais ao âmbito legislativo}

Fala-se, no Brasil, sobre a incapacidade das instituições democráticas de atenderem os reclames da democracia. Sumariza-se em: distorção da igualdade política, da representatividade e da lógica "uma pessoa, um voto"; partidos sem efetiva fixação ideológica, movidos apenas como "legendas de aluguel"; eleições determinadas pelo poderio econômico ${ }^{46}$; perpetuação no poder; controle do Executivo sobre o Legislativo; disfunção do sistema de eleição proporcional, sem garantia de representação das minorias; clientelismo, patrimonialismo e corrupção ${ }^{47}$.

\footnotetext{
${ }^{45}$ WALDRON, Jeremy. Political political theory: essays on institutions. Cambridge: Harvard Univeristy Press, 2016, p. 81-85.

${ }^{46}$ Especificamente sobre este ponto, importa referir que em 2015 o STF declarou inconstitucional o financiamento de campanhas por pessoas jurídicas, trazendo, em meio à vasta gama de fundamentos jurídicos, políticos, aportam dados empíricos relevantes como: (i) aumento de $471 \%$ dos custos com eleições em período de dez anos, encontrando-se o Brasil no topo do ranking de gastos com campanha eleitoral (p. 24-25 e p. 87-90); (ii) participação de $0,5 \%$ do total empresas do país, sendo que, dessas, $1 \%$ das doadoras representa $61 \%$ de todo o montante doado, resultando uma correlação de quase $100 \%$ dos votos recebidos pelos candidatos beneficiados por tais entidadaes (p. 50 e p. 302-303); (iii) as maiores financiadoras são empresas que mantêm contratos com órgãos públicos, em especial no setor de construção civil (p. 172). (BRASIL. Supremo Tribunal Federal. Ação Direta de Inconstitucionalidade n 4650. Rel. Min. Luiz Fux. Tribunal Pleno. Julgado em 17/05/2015). Há dois pontos, que não se confundem, mas merecem reflexão: a legitimidade da decisão e os problemas empíricos apontados em sua fundamentação.
}

${ }^{47}$ Cf. STRECK, Lenio Luiz. Hermenêutica jurídica em crise: uma exploração hermenêutica da construção do Direito. 11. ed. rev., atual. e ampl. Porto Alegre: Livraria do Advogado, 2014, p. 28-36 e 61-63; REIS, Márlon. Eleições 
Há de se averiguar empiricamente esses aspectos. Por isso, a primeira e mais evidente contribuição da obra de Waldron é o fomento ao estudo, debate, teorização e propostas de inovação e aprimoramento do sistema representativo - algo, segundo o autor, pouco explorado na filosofia política e na teoria do direito. Aclamadas conquistas pela via judicial culminaram na aposta exacerbada no âmbito Judiciário, relegando-se a resolução dos problemas do Legislativo a plano secundário, de forma que o descaso sistemático com as instituições democráticas resultou no crescimento expoencial dos problemas verificados em tal ramo do Estado: um dos reflexos da vitória de pirro.

Deve-se abranger o sistema eleitoral, as instituições em si, o processo legislativo e aspectos individuais dos parlamentares. Inclusive, faz-se necessário acompanhar os reflexos das modificações trazidas pela Emenda Constitucional 97/2017, quanto à vedação às coligações no sistema proporcional e requisitos mínimos de representatividade para acesso a recursos do fundo partidário e tempo de propaganda eleitoral. Enfim, o modelo de Waldron, por exemplo, pode embasar olhares críticos, a fim de angariar possibilidades de melhorias.

Tal reclame remonta imediatamente à segunda contribuição vinculada ao âmbito legislativo: a participação e representatividade feminina na política. Denota-se como o sistema proporcional - voltado a facilitar a representação de minorias - é falho, no Brasil, pela porcentagem de mulheres, por exemplo, na Câmara de Deputados. Segundo dados do Tribunal Superior Eleitoral (TSE), apenas 51 dos 513 Deputados Federais eleitos em 2014 são mulheres ${ }^{48}$. Não obstante, 52\% do eleitorado é do sexo feminino ${ }^{49}$. A legislação prevê quota mínima de $30 \%$ para registro de candidatos de cada sexo (artigo 10 , § $3^{\circ}$, Lei 9.504/97), mas, após tal ato, a candidata fica desamparada.

Se o gênero que representa maioria do eleitorado abrange $10 \%$ dos eleitos, pressupõe-se que a cota para registro da candidatura não se mostra medida suficiente para sanar a iniquidade. Veja-se, no atual sistema, adota-se a lista aberta, na qual os candidatos individualmente mais votados são conduzidos às cadeiras da coligação ou partido. Pensam-se em duas alternativas: (i) alocação de porcentagem por gênero a cada determinado número de cadeiras - uma a cada " $x$ " eleitos; ou, (ii) no caso mais remoto

proporcionais em dois turnos: um sistema eleitoral para o país. In: ARANTES, Aldo Silva (Org.). A OAB e a reforma política democrática. Brasília: OAB, 2014, p. 39-50; BARROSO, Luís Roberto. Reforma política no Brasil: os consensos possíveis e o caminho do meio. Texto-base de apresentação na Faculdade de Direito da Universidade de Harvard, 2015. Disponível em: <http://www.luisrobertobarroso.com.br/wp-content/uploads/2017/09/conferencia-OAB.pdf.> Acesso em 24 set. 2017.

${ }^{48}$ Nas eleições, de um total de 4.382 candidatos homens, 462 se elegeram (10,54\%), enquanto das 1.796 candidatas mulheres, apenas 51 se elegeram (2,83\%). TRIBUNAL SUPERIOR ELEITORAL. Estatísticas eleitorais 2014. Disponível em: <http://www.tse.jus.br/eleicoes/estatisticas/estatisticas-candidaturas-2014/copy_of_estatisticas-eleitorais-2014>. Acesso em: 28 set. 2016.

${ }^{49}$ BRASIL. Tribunal Superior Eleitoral. Estatísticas eleitorais 2014. Disponível em: <http://www.tse.jus.br/ eleicoes/estatisticas/estatisticas-candidaturas-2014/copy_of_estatisticas-eleitorais-2014>. Acesso em 28 set. 2016. 
de adoção de lista fechada previamente constituída, a exigência de ao menos uma porcentagem ordenada de cada sexo desde os primeiros candidatos na formação da lista ${ }^{50}$.

A doutrina da sabedoria da multidão (wisdom of the multitude), segundo Waldron, implica que a instituição composta por indivíduos de origens diversas possuirá um "mérito" e uma qualidade epistêmica maior do que outra composta pelos "melhores" (no caso, os eleitos pelo sistema vigente) de origem semelhante. Garantir a multiplicidade de pontos de vista - ao invés da mera participação de 10\% - eleva consideravelmente o mérito da instituição ${ }^{51}$. Não se pode olvidar o sistema eleitoral que, factualmente, mostra-se distorcido.

Já adentrando na terceira contribuição, talvez um dos principais problemas, no Brasil, que se mostra dissonante com a principiologia e estrutura propostas por Waldron seja a (in)dependência do Legislativo em relação ao Executivo e sua influência no processo legislativo, tendendo a tornar-se um mero rito de passagem ${ }^{52}$. Isso assume especial relevância quando, nos primeiros 20 anos da democracia pátria, $83 \%$ do total de leis aprovadas foram iniciativa do Presidente da República (e $75 \%$ dos projetos submetidos ao Legislativo pelo Chefe do Executivo foram aprovados) $)^{53}$.

No Brasil, o presidencialismo de coalizão, voltado a promover maior estabilidade, abrangência e equilíbrio entre interesses ${ }^{54}$, fora desvirtuado por trocas individuais e alinhamentos partidários. Não há vinculação ideológica, mas apenas a instrumentalização da Constituição na busca de interesses privados do Legislativo e Executivo ${ }^{55}$. Refle-

\footnotetext{
${ }^{50} \mathrm{Em}$ ambos os casos, a lógica seria semelhante à aplicada em concursos públicos com cotas para negros e portadores de necessidades especiais: há a lista geral de apuração, e uma lista paralela desses grupos. Nas eleições, quando se alcançasse determinada colocação, se não preenchida a cota mínima de candidatos empossados de cada sexo, eleger-se-ia o mais votado da lista paralela. Em que pese possa parecer uma distorção da igualdade política, trata-se de sua promoção, pois essa pressupõe, além da lógica "uma pessoa um voto", a garantia de uma representatividade razoavelmente igualitária e pluralista.

${ }^{51}$ WALDRON, Jeremy. A dignidade da legislação. Trad. de Luís Carlos Borges. São Paulo: Martins Fontes, 2003, p. 134-137.

${ }^{52} \mathrm{Em}$ escrito sobre problemas do sistema neozelandês, Waldron referiu que cidadãos "devem estar atentos ao quão anômala a situação é - o quão poucas camadas de garantias se têm no processo legislativo, que outros países tomam como certas. [...] não há uma real independência em relação ao Executivo, além de recursos constantes à urgência e ordens de emendas suplementares (Supplementary Order Papers) [...]".(grifou-se) (WALDRON, Jeremy. Parliamentary recklessness: why we need to legislate more carefully. Maxim Institute. Auckland: New Zealand, 2008, p. 26-27).

${ }^{53}$ FIGUEIREDO, Argelina Cheibub; LIMONGI, Fernando. Instituições Políticas e Governabilidade: Desempenho do governo e apoio legislativo da democracia brasileira. In: Carlos Ranulfo Melo; Manuel Alcântara Sáez. (Org.). A Democracia Brasileira: Balanço e perspectivas para o Século 21. Belo Horizonte: UFMG, 2007, p. 147-198.

${ }^{54}$ Importa referir que o Brasil importou parte do sistema dos EUA, mas resguarda um governo de coalizão com forte influência entre Executivo e Legislativo, como no Reino Unido, sem, contudo, difundir-se papel ativo à oposição, o que acaba minando os princípios da teoria política de Waldron - inclusive sua sugestão direta de que um governo de coalizão reclama por uma oposição forte e atuante. Cf. WALDRON, Jeremy. Political political theory: essays on institutions. Cambridge: Harvard Univeristy Press, 2016, p. 113-114.

${ }^{55} \mathrm{Cf}$. STRECK, Lenio Luiz. Os Dilemas da Representação Política: O Estado Constitucional entre a Democracia e o Presidencialismo de Coalizão. Direito, Estado e Sociedade, Rio de Janeiro, n. 44, p. 83-101, jan./jun. 2014, p. 86.
} 
xo da influência do poder econômico e recorrentes casos de corrupção, que dispensam detalhamento.

Sobre isso, um ponto que se depreende do estudo é a liberdade de nomeação de Ministros de Estado no Brasil - diferentemente do exemplo dos Estados Unidos, onde há um procedimento formal e estruturado, com audiências, impugnações e votações à nomeação, mitigando sobremaneira a dependência entre ambas as casas legislativas e o governo. No Brasil, é livre a nomeação, exoneração e retorno ao cargo de parlamentares nomeados Ministros, pela mera conveniência político-partidária, a exemplo da necessidade de angariar votos em deliberações de interesse do Executivo.

Não há a independência entre os poderes reclamada por Waldron ${ }^{56}$, seja pela vedação à participação nos cargos por membros de uma das casas, seja pelo controle substancial por parte do Congresso. A busca a cargos por parlamentares ou pessoas próximas é irrestrita e desvirtua o foco da legislação às "trocas de favores". A coalizão política não representa sucessivamente e em cada eleição uma ideologia certa e determinada ou interesses sociais, algo favorecido pela estrutura eleitoral e supervalorização individual do parlamentar ${ }^{57}$.

\subsection{Do legislativo à atual posição do judiciário no Brasil}

A quarta contribuição aproxima Legislativo e Judiciário. Trata-se das violações ao processo legislativo. O rigor formal e os princípios que regem a deliberação legislativa na teoria de Waldron irradiam nesse ponto. Para exemplificar, apontam-se quatro ocasiões. A primeira é a EC 19/98, promulgada sem os 308 votos necessários, vigendo de 1998 até 2007 , declarada inconstitucional pelo STF ${ }^{58}$.

\footnotetext{
${ }^{56}$ De fato, é improvável algum governo instituir as ideias de desvinculação com o Executivo, pois o que se visa são projetos de lei debatidos e analisados por um corpo representativo independente, sem nada a esperar ou temer dos encarregados de sua administração. Ainda assim enfatizam-se tais princípios para se saber o que falta ao atual quadro. Cf. WALDRON, Jeremy. Political political theory: essays on institutions. Cambridge: Harvard Univeristy Press, 2016, p. 84-85.

57 "[E]m vista dessa estrutura, podemos observar que é por meio de sua participação no governo que o legislador individual terá acesso aos recursos de que necessita para a sobrevivência política, não importando tanto se seu interesse central se volta para a definição de políticas públicas ou para a obtenção e a distribuição de patronagem. Em ambos os casos, seu interesse será atendido por intermédio de sua participação no governo. Assim que o governo é organizado, mediante o acordo formal dos partidos, os líderes dos partidos passam a ser os principais intermediários dos acordos entre o Executivo e os legisladores. Trocam apoio político (votos no Congresso) por acesso à influência política e à patronagem. O Executivo, nesse sentido, fornece aos líderes dos partidos os meios para punir o legislador individual que não seguir a orientação de seu partido, já que aqueles podem negar a este sua cota de patronagem ou de influência política. Por sua vez, o Executivo, considerando os recursos que gerencia, está em uma posição extremamente vantajosa.". CHEIBUB, José Antônio; FIGUEIREDO, Argelina Cheibub; LIMONGI, Fernando. Partidos Políticos e Governadores como determinantes do comportamento legislativo na Câmara dos Deputados. Revista de Ciências Sociais, Rio de Janeiro, v. 52, n. 2, p. 263-299, 2009, p. 290-292.
}

${ }^{58}$ BRASIL. Supremo Tribunal Federal. Ação Direta de Inconstitucionalidade n 2135-MC. Rel. Min. Néri da Silveira. Tribunal Pleno. Julgado em 02/08/2007. 
Em segundo lugar, a EC 65/2009, aprovada no Senado em duas sessões, conforme prescreve a Constituição, mas com menos de uma hora de intervalo entre elas, embora o Regimento Interno daquela casa imponha prazo mínimo de 05 dias $^{59}$. De modo semelhante, a terceira ocasião é a Proposta de Emenda à Constituição (PEC) 182/07, referente à reforma política, sendo o financiamento privado de campanhas rejeitado na votação em um dia e aprovado por emenda aglutinativa no dia seguinte ${ }^{60}$.

Por fim, a PEC 171, relativa à redução da maioridade penal, fora votada e rejeitada em 30 de junho de 2015. Não obstante, no dia seguinte, remanejou-se nova votação pela propositura de emenda aglutinativa, ocasião na qual a PEC fora aprovada, embora o artigo 60 , $55^{\circ}$, da Constituição Federal, proíba expressamente a reapreciação da matéria na mesma sessão legislativa - ou seja, somente poderia ser votada no ano seguinte ${ }^{61}$.

Quando instado a se manifestar sobre as violações procedimentais, o STF tem uma postura deveras passiva e se exime de reconhecer a inconstitucionalidade de tais atos. Por exemplo, na ADI 4.425, o STF reconheceu violação frontal à regra que exige dois turnos de votação em interstício de 05 dias (art. 362 do Regimento Interno do Senado Federal), mas se absteve de declarar a violação ao processo legislativo em face do artigo 60, § 20, da CRFB $/ 88^{62}$. Já no caso da reforma política e financiamento de campanhas, entendeu-se inexistir vício referente ao artigo $60, \S 5^{\circ}$, da $C R F B / 88$, pois a votação das emendas ocorrera em ordem de decrescente de generalidade ${ }^{63}$.

Ora, as práticas do Congresso violaram frontalmente os princípios legislativos de Waldron. Uma regra proposta por Bustamante seria capaz de remediar o problema, a citar: as emendas serem apresentadas antes do início da sessão, permitindo a ciência acerca das diferentes possibilidades, sem risco de pressão política após as votações sucessivas ${ }^{64}$.

\footnotetext{
${ }^{59}$ BUSTAMANTE, Thomas; DE GODOI BUSTAMANTE, Evanilda. Jurisdição Constitucional na Era Cunha: entre o Passivismo Procedimental e o Ativismo Substancialista no STF. Revista Direito e Práxis, Rio de Janeiro, vol. 7, n. 1, p. 346-388, 2016, p. 362-367.

${ }^{60}$ BUSTAMANTE, Thomas; DE GODOI BUSTAMANTE, Evanilda. Jurisdição Constitucional na Era Cunha: entre o Passivismo Procedimental e o Ativismo Substancialista no STF. Revista Direito e Práxis, Rio de Janeiro, vol. 7, n. 1, p. 346-388, 2016, p. 374-378.

${ }^{61}$ MORAIS, Fausto Santos de; DOS SANTOS, José Paulo Schneider. Democracia às escuras?. Empório do direito. Disponível em: <http://emporiododireito.com.br/democracia-as-escuras-por-fausto-santos-de-morais-e-jose-paulo-schneider-dos-santos/>. Acesso em 26 out. 2015.

${ }^{62}$ Como ressalta Bustamante, a norma estaria atendida sem qualquer intervalo entre os dois turnos de votação BUSTAMANTE, Thomas; DE GODOI BUSTAMANTE, Evanilda. Jurisdição Constitucional na Era Cunha: entre o Passivismo Procedimental e o Ativismo Substancialista no STF. Revista Direito e Práxis, Rio de Janeiro, vol. 7, n. 1, p. 346-388, 2016, p. 362-363.

${ }^{63}$ BRASIL. Supremo Tribunal Federal. Mandado de Segurança no 33630 MC. Rel. Min. Rosa Weber. Julgado em 16/06/2015.

${ }^{64}$ BUSTAMANTE, Thomas; DE GODOI BUSTAMANTE, Evanilda. Jurisdição Constitucional na Era Cunha: entre o Passivismo Procedimental e o Ativismo Substancialista no STF. Revista Direito e Práxis, Rio de Janeiro, vol. 7, n. 1, p. 346-388, 2016, p. 382-383. Nesse mesmo sentido de transparência na deliberação e votação, positiva a proibição fixada pelo STF ao "contrabando legislativo", ao vedar a apresentação, na conversão de Medidas
} 
No ordenamento pátrio, há um aparente paradoxo: posturas passivas quanto ao processo legislativo e, como se verá na sequência, o ativismo quanto ao conteúdo da decisão. Violações procedimentais vão à contramão dos preceitos normativos de Waldron sobre autoridade e dignidade da legislação, enquanto o ativismo é criticado pela ilegitimidade democrática. Como esclarece Bustamante, objeções à supremacia judicial não se confundem com ignorar o processo democrático - este é o "pior cenário possível" 65 .

Adentra-se, assim, na quinta contribuição: a necessidade de frear o agigantamento do judiciário (ou supremacia judicial). O STF é responsável por um excessivo espectro de decisões - denomine-se de políticas, morais ou constitucionais. Tal circunstância ganha especial relevância quando, além disso, o Tribunal avoca competências expressamente designadas a órgãos do Poder Legislativo.

Veja-se o caso do artigo 52, X: na Reclamação 4.335/AC ${ }^{66}$, o STF apontou não ser necessário submeter ao Senado lei declarada inconstitucional pelo controle difuso para suspender-lhe a eficácia ${ }^{67}$. No mesmo sentido, a flutuação do STF sobre a necessidade de pronunciamento pelo Legislativo para perda do mandato parlamentar em decorrência de condenação criminal, à luz do artigo 55 , $§ 2^{\circ}$, da CRFB/88. A título de exemplificação, no MS 32.326/DF68, cassou-se parlamentar diretamente em decorrência de condenação criminal, embora a Constituição atribua essa tarefa à respectiva casa do Congresso (no caso julgado, à Câmara de Deputados). Por fim, em decisão monocrática no MS 34.087/DF, o Min. Marco Aurélio determinou a instauração de processo de

Provisórias em lei, de emendas sem pertinência temática com o ato normativo em apreciação (BRASIL. Supremo Tribunal Federal. Ação Direta de Inconstitucionalidade no 5127. Rel. Min. Rosa Weber. Relator para o acórdão: Rel. Min. Edson Fachin. Tribunal Pleno. Julgado em 15/10/2015).

${ }^{65}$ BUSTAMANTE, Thomas; DE GODOI BUSTAMANTE, Evanilda. Jurisdição Constitucional na Era Cunha: entre o Passivismo Procedimental e o Ativismo Substancialista no STF. Revista Direito e Práxis, Rio de Janeiro, vol. 7, n. 1, p. 346-388, 2016, p. 359-365. Semelhante foi a postura do Tribunal ao afastar o artigo $62, \S 9^{\circ}$, da CRFB/88, modulando efeitos da inconstitucionalidade de centenas de medidas provisórias convertidas em lei sem submissão à comissão de deputados e senadores para análise dos requisitos de relevância e urgência, violando frontalmente tal artigo. Afirma Streck: "a Corte se transformou em uma espécie de poder constituinte derivado de fato, alterando formalmente o texto da Constituição". STRECK, Lenio Luiz. Os Dilemas da Representação Política: O Estado Constitucional entre a Democracia e o Presidencialismo de Coalizão. Direito, Estado e Sociedade, Rio de Janeiro, n. 44, p. 83-101, jan./jun. 2014.

${ }^{66}$ BRASIL. Supremo Tribunal Federal. Reclamação no 4335. Rel. Min. Gilmar Mendes. Tribunal Pleno. Julgado em 20/03/2014.

${ }^{67}$ No debate, os Ministros abordaram a ocorrência de "mutação constitucional" (p. 53), atribuindo-se à decisão da Corte efeitos gerais, possuindo a suspensão da lei pelo Senado mero efeito de publicidade (p. 55). Outrossim, salientou-se que as decisões do Tribunal em controle difuso são dotadas de "eficácia expansiva", independentemente da manifestação do Senado Federal (p. 150). No caso, o agregado dos votos não fixou peremptoriamente a modificação do artigo 52, X, da CRFB/88, e qual a abrangência da eficácia expansiva ou ultra partes da decisão em controle difuso, pois o caso fora resolvido em face da posterior edição de Súmula Vinculante (p. 170-181 e 194-195).

${ }^{68}$ BRASIL. Supremo Tribunal Federal. Mandado de Segurança n 32326-MC. Rel. Min. Luís Roberto Barroso. Julgado em 02/09/2013. 
impeachment do Presidente da República, tarefa afeta à Câmara dos Deputados ${ }^{69}$ pelo artigo 51, l, e artigo 86, da CRFB/88.

Note-se que o próprio STF amplia suas competências e remodela a separação de poderes contida na Constituição. Curioso, por se tratar do órgão designado como "guardião da Constituição" que, por vezes, invoca cláusulas pétreas (artigo 60, § 4, CRFB/88) ao vetar decisões ou projetos legislativos, inclusive de Emendas à Constituição. Agora, não há meio de invocar a cláusula pétrea originária da separação de poderes para barrar excessos do Tribunal.

Ademais, decisões que vão, em tese, na contramão da literalidade da Constituição, merecem olhares atentos. Notadamente, o caso das uniões homoafetivas (ADI 4.277/DF ${ }^{70}$ quanto ao artigo 226, da CRFB/88, e artigo 1.723 do Código Civil) e o cumprimento provisório ou antecipado da pena (HC 126.292/SP71, quanto ao artigo 5०, LVI, da CRFB/88 e artigo 283, do Código de Processo Penal - CPP). Por fim, há decisões de cunho eminentemente político, a exemplo da definição do aborto até o terceiro mês de gestação como fato atípico, embora os artigos 124 a 128, do Código Penal, regulamentem a conduta como crime (HC 124.306/RJ $\left.{ }^{72}\right)$.

Tais apontamentos remontam características daquilo que Waldron denomina de judicial supremacy: a substituição do autogoverno pelos Tribunais; a soberania do Judiciário, não sujeito a controle ou revisão; e a usurpação do poder constituinte - a corte vista como "continuamente fazendo a constituição". Nesse contexto, o tribunal determina o rumo ideológico da nação com base nas suas convicções, impõe aos demais poderes "como deve ser lida" a Constituição e adota alguma visão geral de justiça ou política, sendo que a mera mudança de membros pode alterar o entendimento da corte ${ }^{73}$.

Enfim, a gama de questões cuja palavra final se dá pelo STF é irrestrita ${ }^{74}$. Por isso, busca-se uma análise concomitante sobre os aspectos quantitativos e qualitativos. Ou

\footnotetext{
${ }^{69}$ Trata-se de atribuição do Presidente da Casa Legislativa, segundo artigo 218, § $2^{\circ}$, do Regimento Interno da Câmara dos Deputados.

${ }^{70}$ BRASIL. Supremo Tribunal Federal. Ação Direta de Inconstitucionalidade n 4277. Rel. Min. Ayres Britto. Tribunal Pleno. Julgado em 05/05/2011

${ }^{71}$ BRASIL. Supremo Tribunal Federal. Habeas Corpus n 126292. Min. Rel. Min. Marco Aurélio. Relator para o acórdão: Rel. Min. Roberto Barroso. Primeira Turma. Julgado em 09/08/2016.

${ }^{72}$ BRASIL. Supremo Tribunal Federal. Habeas Corpus n 126292. Min. Rel. Min. Marco Aurélio. Relator para o acórdão: Rel. Min. Roberto Barroso. Primeira Turma. Julgado em 09/08/2016.
}

${ }^{73}$ WALDRON, Jeremy. Judicial Review and Judicial Supremacy. Public Law and Legal Theory Research, New York, p. 14-57, 2014. Disponível em: <http://ssrn.com/abstract=2510550>. Acesso em: 12 nov. 2015.

${ }^{74}$ Uma rápida lista exemplificativa, além dos citados ao longo do presente escrito: infidelidade partidária (MS 26.602, MS 26.603, MS 26.604 e ADI 5.081); cláusula de barreira nas eleições proporcionais (ADI 1.351 e 1.354); requisitos para criação de partidos políticos (ADI 5.311); acesso ao fundo partidário e propaganda eleitoral (ADI 5.105); aborto de fetos anencéfalos (ADPF 54); Lei da Ficha Limpa (ADI 4578 e ADCs 29 e 30); pesquisas com células tronco-embrionárias (ADI 3510); royalties do petróleo (ADI 4.917); publicação de biografias e autorização do biografado (ADI 4.815), cotas raciais em processos seletivos públicos (ADPF 186 e ADC 41); práticas culturais e/ou desportivas que ensejariam, em tese, tortura ou maus-tratos a animais (ADI 1856, RE 153.531 e ADI 4.983) direitos de processados criminalmente (HC 82.959, HC 111.840 e HC 118.533, entre outros), proibição do uso 
seja: se é adotado um controle forte e concretista, deve-se garantir o melhor sistema possível, pois há uma consistente crítica à prática estabelecida. Defender o controle não pode significar o mesmo que fechar os olhos a problemas de um cenário merecedor de maior cuidado $^{75}$, sob pena de a jurisdição constitucional representar, novamente, verdadeira vitória pírrica.

\subsection{Aspectos intrínsecos ao âmbito judicial}

Como sexta contribuição, uma abordagem qualitativa demanda por análise estrutural e procedimental do STF. Nessa perspectiva, necessita-se de atenção a regras e práticas internas do tribunal que podem afetar a qualidade da deliberação, uma vez que merece reflexões o modo de decisão puramente agregativo adotado na Corte, com a soma de onze votos avulsos, pré-redigidos e sem deliberação entre os Ministros ${ }^{76}$.

Virgílio Afonso da Silva expõe dois aspectos favorecidos pela deliberação efetiva: a) o compartilhamento de opiniões e informações desconhecidas por outros membros; e b) a atenuação da limitação ínsita à racionalidade individual pela intensa troca de argumentos que leva a esclarecimentos recíprocos, numa espécie de brainstorming capaz de construir soluções coletivas. Com isso, quer-se evidenciar que o Tribunal não está sendo capaz de cumprir as promessas dos defensores do judicial review ${ }^{77}$.

Com efeito, um ponto inicial (que parece ser aceito pelos membros do STF) é a distribuição e acesso ao voto do relator antes da sessão de julgamento, propiciando delimitação ao debate e mitigando os longos votos pré-redigidos ${ }^{78}$. Posteriormente, pode-se pensar na aproximação do Tribunal a um caráter deliberativo, com decisões

\footnotetext{
de medicamento não testado que havia sido liberado por lei (ADI 5.501), determinação de obras em presídios (RE 592.581/RS), entre uma vasta lista. Mais recentemente, verificou-se a tendência pela admissão do aborto até o $3^{\circ}$ mês de gestação (HC 124.306/RJ). Isso além de outras matérias ainda pendente de julgamento como, por exemplo, descriminalização da maconha (RE 635.659) e a possibilidade de manutenção de banco de dados genéticos de condenados criminalmente (RE 973.837).

${ }^{75}$ Nesse sentido, Waldron dirá que o quadro normativo ideal por ele desenhado não implica descaso com situações em que o processo legislativo se torna um mero "rito de passagem". Depois de assentados seus argumentos no plano ideal, o autor reconhece que é uma questão à parte verificar se as instituições abraçaram ou não a oportunidade de funcionar da melhor forma possível. WALDRON, Jeremy. Refining the question about judges' moral capacity. International Journal of Constitutional Law (I-CON), Oxford vol. 7, n. 1, p. 69-82, 2009, p. 79. E isso diz respeito tanto a um olhar sobre o Legislativo - para talvez legitimar o judicial review - quanto um olhar sobre as instituições judiciais, uma vez já assentado o controle de constitucionalidade.
}

${ }^{76}$ SILVA, Virgílio Afonso da. O STF e o controle de constitucionalidade: deliberação, diálogo e razão pública. Revista de Direito Administrativo, Rio de Janeiro, vol. 250, p. 197-227, 2009.

77 SILVA, Virgílio Afonso da. Deciding without deliberating. International Journal of Constitutional Law, Oxford, vol. 11, n. 3, p. 557-584, jul./sept. 2013, p. 557-560.

${ }^{78}$ SILVA, Virgílio Afonso da. "Um voto qualquer"? O papel do Ministro Relator na deliberação no Supremo Tribunal Federal. Revista Estudos Institucionais, Rio de Janeiro, vol. 1, n. 1, p. 180-200, jul./dez. 2015. 
unas, e não votos avulsos, repensando questões como a excessiva publicidade enquanto forma de refutar certas posturas individualistas dos Ministros ${ }^{79}$.

Outrossim, salienta-se a proposta de Oscar Vilhena Vieira de "deliberação em três etapas", em prol da transparência e deliberação. Primeiramente, selecionar os casos do controle difuso a serem julgados no ano judiciário ${ }^{80}$, enquanto os de controle concentrado são julgados pela ordem de entrada. Em segundo lugar, abre-se espaço para audiências públicas e sustentações orais com participação obrigatória dos Ministros. Por fim, sessões de discussão e julgamento, com a tarefa de redigir o acórdão sendo atribuída a um único Ministro - quem liderou a maioria - e não onze votos avulsos. Isso demanda, certamente, a redução de competências da Corte, como foco nas atribuições de Tribunal Constitucional ${ }^{81}$.

Ademais, a argumentação do STF tornou-se verdadeira "demonstração de erudição", com citações da doutrina e jurisprudência do apreço de cada Ministro. Sabe-se o resultado final da decisão, mas não se consegue identificar sua ratio decidendi, nem suas consequências a casos futuros. A soma de opiniões faz com que a decisão do Tribunal pareça emergir porque "aquele conjunto de pessoas, circunstancialmente escolhidas e decidindo, assim o quis"82.

Se a legitimidade política é uma questão comparativa, mesmo que fomentar o caráter deliberativo e a transparência do Tribunal não o equiparem à do Legislativo, ao menos se reduz o déficit. Waldron, mesmo sem conseguir definir a fundamentação teórica da adoção do voto majoritário nos Tribunais, dirá que tal sistema não obsta a deliberação por princípios, sendo, pelo contrário, parte daquilo que tal deliberação envolve ${ }^{83}$. Por isso, mantido um sistema baseado no voto dos Ministros, em oposição à decisão per curiam, algum grau de deliberação precisa ser implementado ${ }^{84}$.

\footnotetext{
${ }^{79}$ SILVA, Virgílio Afonso da. Deciding without deliberating. International Journal of Constitutional Law, Oxford, vol. 11, n. 3, p. 557-584, jul./sept. 2013, p. 576-583.

${ }^{80}$ Sobre a definição da pauta do STF há pontos que merecem maior abordagem. Primeiramente, faz-se por critérios discricionários, com mecanismos para se adiar de modo incerto o desfecho da decisão, como o voto-vista (em que um Ministro pode interromper o julgamento para "refletir sozinho", e decisões liminares monocráticas que são supostamente provisórias, mas que efetivamente encerram a atuação do Tribunal. Cf. MENDES, Conrado Hübner. Direitos fundamentais, separação de poderes e deliberação. São Paulo: Saraiva, 2011, p. 255-256 e 269. Em segundo lugar, a estratégia de definição da pauta de julgamentos e os poderes do relator de liberar os processos para entrarem na agenda do Tribunal. Cf. SILVA, Virgílio Afonso da. "Um voto qualquer"? O papel do Ministro Relator na deliberação no Supremo Tribunal Federal. Revista Estudos Institucionais, Rio de Janeiro, vol. 1, n. 1, p. 180-200, jul./dez. 2015
}

${ }^{81}$ VIEIRA, Oscar Vilhena. Supremocracia. Revista Direito GV, São Paulo, vol. 4, n. 2, p. 445-463, jul./dez. 2008.

${ }^{82}$ ROESLER, Claudia Rosane. Entre o paroxismo de razões e a razão nenhuma: paradoxos de uma prática juridical. Revista de Direito da Universidade de Brasília, Brasília, vol. 2, n. 1, p. 79-95, 2016, p. 84-91.

${ }^{83}$ WALDRON, Jeremy. Political political theory: essays on institutions. Cambridge: Harvard Univeristy Press, 2016, p. 250 e 272.

${ }^{84}$ Aspecto que se beneficia da legitimidade como questão comparativa, como apontamento positivo da atuação do STF, é a paulatina institucionalização, além do amicus curiae, também das audiências públicas. Tal prática eleva a participação democrática ao viabilizar que demandas e visões sociais contemporâneas da 
Sobre os limites da jurisdição constitucional, outro ponto que se coaduna, em parte, com as lições de Waldron é a crítica à inadequada recepção do "princípio da proporcionalidade" no Brasil - com forte aplicação pelo STF em sede de controle de constitucionalidade. Consta-se que não há critérios intersubjetivos, nem respeito à teoria que difundiu a proporcionalidade (de Robert Alexy), quando da aplicação de princípios por aquele incumbido de tomar a decisão, de tal forma que acabam sendo originados e sopesados arbitrariamente pelo intérprete. A devida fundamentação das decisões, reclame democrático, exige afastamento da discricionariedade e ativismo judiciais ${ }^{85}$ aspectos cada vez mais presentes na atividade jurisdicional e que denotam a referida vitória pírrica.

Por fim, adentra-se na sétima e última contribuição aqui abordada: o modelo de controle de constitucionalidade. Para tanto, lança-se mão da ideia apontada por Hübner Mendes, o qual argumenta que há um constante "diálogo institucional" mediante uma série infindável de rodadas deliberativas entre Tribunal e Parlamento, em que uma instituição pode deferir à decisão da outra, ou se esforçar para superar os argumentos lançados e reformá-la. O citado autor trata inicialmente de casos de inconstitucionalidade por omissão, nos quais acredita-se que a crítica de Waldron perde força, pois, com a decisão judicial, almeja-se apenas compelir o Legislativo a legislar, sem precluir o conteúdo resultante da deliberação parlamentar ${ }^{86}$.

No entanto, outra análise deflagrada pela ideia de diálogos institucionais remonta ao viés preventivo da jurisdição constitucional. Pode-se refletir sobre a atuação da Comissão de Constituição e Justiça (CCJ), encarregada, nas casas do Congresso Nacional, do juízo prévio sobre a constitucionalidade da matéria ainda na tramitação da $1 \mathrm{ei}^{87}$.

população sejam debatidas no âmbito da justiça constitucional, além de permitir que perspectivas diversas sobre considerações factuais, políticas e de interpretação constitucional sejam contrapostas. A "última palavra" é do Tribunal, mas há participação popular - e dos demais Poderes -, pela canalização de interesses da sociedade, de âmago substancial e procedimentalmente legislativos, até então apartados da jurisdição constitucional. Cf. TUSHNET, Mark. New institutional mechanisms for making constitutional law. In: BUSTAMANTE, Thomas; FERNANDES, Bernardo Gonçalves (Orgs.). Democratizing constitutional law: perspectives on legal theory and the legitimacy of constitutionalism. Heidelberg: Springer, 2016, p. 179-183.

${ }^{85}$ MORAIS, Fausto Santos de. Ponderação e arbitrariedade: a inadequada recepção de Alexy pelo STF. Salvador: Juspodivm, 2016, p. 243-253, e passim.

${ }^{86}$ Veja-se, casos como o direito de greve dos servidores públicos (MI 670, 708 e 712), permanecem desde a promulgação da CF/88 sem regulamentação legislativa, sanados pela via judicial. Isso dentre outros dispositivos que até hoje não possuem qualquer reflexo normativo forma do texto constitucional. A adoção da teoria concretista pelo STF no Mandado de Injunção (vide MI 670, 708 e 712), ratificada pela Lei 13.300/16 é verdadeiro avanço. O mesmo deveria ocorrer com a Ação Direta de Inconstitucionalidade por Omissão, pois o efeito de cientificar o legislativo acerca da mora não atende às necessidades de uma democracia constitucional. Se Medidas Provisórias são aptas a trancar a pauta do parlamento para apreciação, por que uma omissão constitucional não é vista com a mesma relevância e urgência?

${ }^{87} \mathrm{Cf}$. BARROSO, Luís Roberto. $\mathbf{O}$ controle de constitucionalidade no direito brasileiro. 5. ed. rev. e atual. São Paulo: Saraiva, 2011, p. 95. 
Merecem considerações sua composição, estruturação e procedimentos de decisão. Ademais, a adoção de diálogos prévios com manifestação da Corte Constitucional, pode alavancar a qualidade sobre o conteúdo da matéria. Talvez, em alguma medida, seja positiva a vinculação (temporal, parcial do projeto ou sujeita a referendo após decisão do Tribunal) ${ }^{88}$ das decisões da CCJ, embasadas nesse diálogo. Com ou sem vinculação, o diálogo traria benefícios e aprimoraria a qualidade epistêmica da decisão da casa legislativa pela perspectiva jurídico-constitucional. Afinal, a ideia é prevenir violações a direitos. A interação certamente atenderia aos pressupostos epistêmicos e princípios legislativos, com enfoque no "dever de cuidado" reclamado por Waldron, com deliberação responsiva e não meramente formal.

Até o presente momento, as propostas demonstram uma apropriação tangencial daquilo que Waldron propõe. Não obstante, em conjunto com tais propostas - como garantia do razoável bom funcionamento da democracia -, em um segundo momento e, factivelmente, a longo prazo, pode-se refletir sobre mudanças substanciais, notadamente pela adoção de um controle fraco de constitucionalidade (weak judicial review) ${ }^{89}$.

Reporta-se ao modelo do Reino Unido, no qual a declaration of incompatibility é o procedimento pelo qual Tribunais averiguam a lei e, se impossível interpretá-la em conformidade ao Human Rights Act (1998), declaram sua incompatibilidade com referido diploma, sem negar-lhe validade ou aplicação ao caso. Todavia, alguma autoridade (no caso, o Primeiro-Ministro) detém competência para, a partir dessa decisão, submeter a lei a procedimento sumário de revisão perante o parlamento ${ }^{90}$.

\footnotetext{
${ }^{88}$ Resguardadas as diferenças históricas e contextuais, o modelo de controle preventivo e de natureza política adotado na França - único mecanismo até o advento do controle repressivo plenamente assentado em 2010. Trata-se de órgão especializado - Conselho Constitucional - atuante após a votação parlamentar e antes da promulgação da lei. Há de se refletir sobre aspectos e peculiaridades de cada sistema: (i) a composição do órgão; (ii) o fato de que na França o Conselho é o próprio órgão constitucional; (iii) se a submissão a esse mecanismo seria sempre compulsório ou apenas quando arguido por alguma autoridade; (iv) se o amparo epistêmico é melhor alcançado pela manifestação antes ou após a deliberação parlamentar; (v) como o foco é o diálogo institucional, se é adequada para esse propósito a vinculação da manifestação como o é na Corte francesa, ou se a decisão retornará para escrutínio do Legislativo, permitindo-se reapreciar, corrigir, ou superar a manifestação do órgão que efetua o controle. Cf. STRECK, Lenio Luiz. Jurisdição constitucional e decisão jurídica. 4. ed. São Paulo: Editora Revista dos Tribunais, 2014, p. 404-408 e CAPPELLETTI, Mauro. 0 controle de constitucionalidade no direito comparado. Trad. de Aroldo Plínio Gonçalves. Porto Alegre, 1984, p. 94-99.

${ }^{89}$ Institutos de controle fraco seriam oportunidades de "restrição moral" ao Legislativo, e a crítica de Waldron não se volta a tais sistemas, pois diferenciam-se substancialmente nos aspectos formais de poder - especialmente nas possibilidades de contribuição e oposição. WALDRON, Jeremy. Refining the question about judges' moral capacity. International Journal of Constitutional Law (I-CON), Oxford vol. 7, n. 1, p. 69-82, 2009, p. 76-78.

${ }^{9}$ WALDRON, Jeremy. The core case against judicial review. The Yale Law Journal, New Haven vol. 115, n. 6, p. 1346-1406, apr. 2006, p. 1355 e p. 1370. WALDRON, Jeremy. Judges as moral reasoners. International Journal of Constitutional Law (I-CON), Oxford, vol. 7, n. 1, p. 2-24, 2009, p. 23-24; WALDRON, Jeremy. Refining the question about judges' moral capacity. International Journal of Constitutional Law (I-CON), Oxford vol. 7, n. 1, p. 6982, 2009, p. 76-78; MENDES, Conrado Hübner. Direitos fundamentais, separação de poderes e deliberação. São Paulo: Saraiva, 2011, p. 161-162. Os dispositivos sobre tal instituto se encontram nas seções três e quatro do Human Rights Act, de 1998 (http://www.legislation.gov.uk/ukpga/1998/42/contents).
} 
Argumento recorrente contra arranjos com maior força ao Legislativo é que tal âmbito se sujeita à pressão popular e eleitoral. Portanto, remeter-lhe decisões do Tribunal para veto ou sanção pode sofrer positivamente desse efeito, pois órgãos representativos teriam grande ônus político para sobrepujar-se à decisão da Corte e só o fariam se tivessem boas razões para tanto.

Dworkin, por exemplo, argumenta que o judicial review merece primazia por ser meio de reascender e aprimorar o debate sobre a matéria ${ }^{91}$. Nesse sentido, o intuito do diálogo entre Corte Constitucional e Legislativo aqui proposto seria reascender o debate e a atenção do povo em dois aspectos: (i) quanto à matéria discutida; e (ii) sobre a postura de seus representantes eleitos. Isso não ocorre se a decisão é deixada ao Tribunal, pois embora o tema seja trazido à tona, a população não tem a oportunidade de assistir às opiniões e à atuação de seus representantes, ficando a questão fadada ao esquecimento após decidida pelo seleto grupo de juízes, sem efeito institucional, mas apenas material. A longo prazo, diminui-se a atenção do povo à atuação política de seus representantes e ofuscam-se possibilidades de diálogo. Frise-se: uma vitória pírrica.

Vejam-se duas consequências concretas. Primeiramente, a supremacia judicial no Brasil fez com que um mecanismo de diálogo fosse paulatinamente - até o momento parcialmente - anulado pelo STF, ao driblar o papel do Senado em suspender a eficácia da lei declarada inconstitucional pelo controle difuso, conforme já exposto. Em segundo lugar, os debates no legislativo após a decisão judicial permanecem à margem da população, a exemplo da decisão do STF sobre a inconstitucionalidade da vaquejada (ADI 4983) ${ }^{92}$ : "reaceso o debate", o Congresso editou EC n 96/17, declarando a prática manifestação cultural nacional.

Nesse último caso, não se pode dizer que houve diálogo institucional genuíno, e sim efeito backlash, em sentido próximo ao de Michael J. Klarman ${ }^{93}$ ou Cass Sunstein ${ }^{94}$ : circunstância na qual a resolução judicial de questão altamente controvertida gera extrema reprovação pela parcela contrária da população e representantes eleitos que se opõem à decisão ${ }^{95}$. Nesse contexto, discursos conservadores perquirirão, de forma inflexível e insuscetível ao debate, todos os meios possíveis até que revertam a decisão tomada. Ou seja, a influência na opinião pública gera, ao final, duplo revés: primeiro, no debate sobre o tema,

\footnotetext{
${ }^{91}$ DWORKIN, Ronald. Freedom's Law: the moral reading of the American Constitution. New York: Oxford University Press, 1996, p. 345-347.

${ }^{92}$ BRASIL. Supremo Tribunal Federal. Ação Direta de Inconstitucionalidade no 4983. Rel. Min. Marco Aurélio. Tribunal Pleno. Julgado em 06/10/2016.

${ }^{93}$ KLARMAN, Michael J. How Brown changed race relations: the backlash thesis. The Journal of American History, Oxford, vol. 81, n. 1, p. 81-118, jun. 1994.

${ }^{94}$ SUNSTEIN, Cass. A Constitution of many minds: why the founding document doesn't mean what it meant before. New Jersey: Princeton University Press, 2009, p. 124-139.

${ }^{95}$ Ressalta-se que há autores que elencam consequências positivas ao efeito backlash. Por exemplo, ver POST, Robert C.; SIEGEL Reva B. Roe Rage: Democratic constitutionalism and backlash. Harvard Civil Rights-Civil Liberties Law Review, Cambridge, vol. 42, n. 2, p. 373-433, 2007.
} 
que fica imunizado ao diálogo após a decisão; segundo, no regramento da matéria, o qual retorna ao status anterior, ou até mesmo regride, ao invés de gerar os efeitos progressistas pretendidos.

Por outro lado, a ideia da legitimidade democrática de Waldron exige debate público sobre a matéria, e não de modo impensado por pura repulsa à opinião do grupo opositor. Isto é, não se pode abdicar da accountability ou responsabilidade política inerentes à tomada de decisão. Nesse viés, o efeito pretendido por uma decisão no controle fraco de constitucionalidade seria justamente reascender o diálogo genuíno sobre a matéria, em atenção a princípios legislativos como aqueles delineados por Waldron.

O verdadeiro diálogo institucional é mais propenso à legitimidade democrática. O Tribunal estaria constantemente examinando, questionando e exigindo explicações e argumentações consistentes do Legislativo ${ }^{96}$, sem retirar do povo e seus representantes, formalmente, o autogoverno.

Países que adotam o sistema de weak judicial review possuem mecanismos para destacar violações a direitos ou aspectos não levados em conta e incluí-los no debate, ainda no trâmite legislativo. O exemplo trazido por Waldron é o ordenamento jurídico da Nova Zelândia, no qual não há controle de constitucionalidade ${ }^{97}$, mas o Procurador-Geral, após a apresentação do projeto, deve trazer à atenção da casa legislativa previsões que aparentem ser incompatíveis com direitos ou liberdades constantes da New Zealand Bill of Rights Act (1990) ${ }^{98}$. Algo nesse sentido, concomitante à atuação supracitada da Comissão de Constituição e Justiça em conjunto com a Corte Constitucional, também poderia ser implementado em conjunto ao controle fraco.

Esse arcabouço de weak review satisfaria, em tese, pontos levantados no decorrer do trabalho: (i) não carece de legitimidade democrática; (ii) enseja a constante preocupação com âmbito legislativo, ao invés de relegarem-se todos os cuidados ao âmbito

\footnotetext{
${ }^{96}$ Quando da explicação sobre accountability democrática e judicial, Waldron destaca qual pode ser o papel do controle judicial: "forma mediada de accountability democrática, com escrutínios pela corte ajudando a focar em processos mais amplos de acocuntability democrática e com os procedimentos da corte operando insistentemente para requer que os legisladores e outros agentes públicos a prestar informações do que estão fazendo (to give na account of themselves), as quais então estarão disponíveis ao povo. É análogo à accountability dos membros do Executivo (cabinet) e outros sob juramento ao comitê legislativo". WALDRON, Jeremy. Political political theory: essays on institutions. Cambridge: Harvard Univeristy Press, 2016, p.193.

${ }^{97}$ Existe, contudo, o dever de Tribunal esforçar-se em interpretar a lei de forma a evitar violações por ele reconhecidas. Cf. WALDRON, Jeremy. The core case against judicial review. The Yale Law Journal, New Haven vol. 115, n. 6, p. 1346-1406, apr. 2006, p. 1356. Ao comparar o sistema neozelandês e o modelo canadense, Conrado Hubner Mendes explica: "[u]ma lei inconsistente com a Declaração não pode ser invalidada judicialmente, mas a corte controlaria o eu significado. [...] na Nova Zelândia [...], juízes têm sido entusiastas na proteção de direitos, um bom exemplo de que soluções institucionais semelhantes surtem efeitos diferentes na respectiva cultura em que decantam. $O$ arranjo criado deixa a última palavra com o parlamento, mas pretende induzi-lo a levar direitos a sério e a estar plenamente informado sobre as questões de direitos por trás de sua decisão." MENDES, Conrado Hübner. Direitos fundamentais, separação de poderes e deliberação. São Paulo: Saraiva, 2011, p. 161.

${ }^{98}$ WALDRON, Jeremy. The core case against judicial review. The Yale Law Journal, New Haven vol. 115, n. 6, p. 1346-1406, apr. 2006, p. 1370 e 1378; WALDRON, Jeremy. Judges as moral reasoners. International Journal of Constitutional Law (I-CON), Oxford, vol. 7, n. 1, p. 2-24, 2009, p. 23-24.
} 
judicial; (iii) fomenta a responsabilidade e accountability dos representantes eleitos, pois a vigilância do povo será ainda maior diante de apontamentos, pelo Tribunal, de supostas violações a direitos; (iv) eleva a qualidade epistêmica das decisões, pelo diálogo institucional entre Judiciário e Legislativo, de forma que o último se vê na obrigatoriedade de responder ao primeiro aos olhos da população, efetivamente em diálogo institucional, e não como mera represália à decisão da Corte.

Enfim, frise-se que todas as propostas e indicações aqui apresentadas são perspectivas em processo de germinação, com o intuito de demonstrar que é possível extrair contribuições substanciais à realidade institucional pátria pelo estudo da obra de Waldron, a partir de suas fortes críticas à jurisdição constitucional e crença nas instituições democráticas. E tais contribuições irradiam sobre todos os poderes do Estado.

\section{CONSIDERAÇÕES FINAIS}

Depreende-se do estudo realizado que há uma série de possíveis contribuições a se extraírem do aparato teórico fornecido por Waldron, e não apenas ao âmbito judicial, mas também ao poder Legislativo e ao Executivo. Desde aspectos estruturais ou peculiares do funcionamento de cada instituição, até mudanças mais substanciais ao sistema podem (e devem) ser pensados. Inclusive, o fomento à discussão de aspectos institucionais comumente relegados ao esquecimento, por si, já é uma importante contribuição.

Limitar-se a comemorar cegamente resultados particulares obtidos pela jurisdição constitucional pátria não se revelará nada além de uma verdadeira vitória pírrica inicialmente comemorada, mas que acarreta altos custos. No atual estágio da democracia brasileira, os altos custos acarretam não só o agigantamento do Judiciário, mas também a paulatina desatenção e esquecimento de aspectos inerentes ao âmbito legislativo.

Tais conclusões são definitivas para o propósito deste trabalho - estudar a teoria de Waldron e abordar perspectivas iniciais sobre a possibilidade de contribuições às instituições pátrias. Todavia, merecem maior aprofundamento em cada um de seus aspectos e argumentos, adentrando-se empírica e normativamente na análise contextual do Brasil, investigando-se a atividade judicial e legislativa pátrias na comparação dos modelos atualmente vigentes, seja com as propostas de Waldron, seja com outros arranjos possíveis, a fim aprofundar-se em contribuições mais concretas. Contudo, isso remanescerá objeto de estudos futuros.

\section{REFERÊNCIAS}

BRASIL. Supremo Tribunal Federal. Ação Direta de Inconstitucionalidade n 2135-MC. Rel. Min. Néri da Silveira. Tribunal Pleno. Julgado em 02/08/2007.

BRASIL. Supremo Tribunal Federal. Ação Direta de Inconstitucionalidade n 4277. Rel. Min. Ayres

Britto. Tribunal Pleno. Julgado em 05/05/2011. 
BRASIL. Supremo Tribunal Federal. Ação Direta de Inconstitucionalidade n 4983. Rel. Min. Marco Aurélio. Tribunal Pleno. Julgado em 06/10/2016.

BRASIL. Supremo Tribunal Federal. Ação Direta de Inconstitucionalidade no 4650. Rel. Min. Luiz Fux. Tribunal Pleno. Julgado em 17/05/2015.

BRASIL. Supremo Tribunal Federal. Ação Direta de Inconstitucionalidade n 5127. Rel. Min. Rosa Weber. Relator para o acórdão: Rel. Min. Edson Fachin. Tribunal Pleno. Julgado em 15/10/2015.

BRASIL. Supremo Tribunal Federal. Habeas Corpus n 126292. Min. Rel. Min. Marco Aurélio. Relator para o acórdão: Rel. Min. Roberto Barroso. Primeira Turma. Julgado em 09/08/2016.

BRASIL. Supremo Tribunal Federal. Mandado de Segurança n 32326-MC. Rel. Min. Luís Roberto Barroso. Julgado em 02/09/2013.

BRASIL. Supremo Tribunal Federal. Mandado de Segurança no 33630 MC. Rel. Min. Rosa Weber. Julgado em 16/06/2015.

BRASIL. Supremo Tribunal Federal. Reclamação n 4335. Rel. Min. Gilmar Mendes. Tribunal Pleno. Julgado em 20/03/2014.

BRASIL. Tribunal Superior Eleitoral. Estatísticas eleitorais 2016 - Eleitorado. Disponível em: <http://www.tse.jus.br/eleicoes/estatisticas/estatisticas-eleitorais-2016/eleicoes-2016>. Acesso em 28 set. 2016.

BRASIL. Tribunal Superior Eleitoral. Estatísticas eleitorais 2014. Disponível em: <http://www.tse. jus.br/eleicoes/estatisticas/estatisticas-candidaturas-2014/copy_of_estatisticas-eleitorais-2014>. Acesso em 28 set. 2016.

BARROSO, Luís Roberto. $\mathbf{O}$ controle de constitucionalidade no direito brasileiro. 5. ed. rev. e atual. São Paulo: Saraiva, 2011.

BARROSO, Luís Roberto. Reforma política no Brasil: os consensos possíveis e o caminho do meio. Texto-base de apresentação na Faculdade de Direito da Universidade de Harvard, 2015. Disponível em: <http://www.luisrobertobarroso.com.br/wp-content/uploads/2017/09/conferencia-OAB. pdf $>$. Acesso em 24 set. 2017.

BUSTAMANTE, Thomas; DE GODOI BUSTAMANTE, Evanilda. Jurisdição Constitucional na Era Cunha: entre o Passivismo Procedimental e o Ativismo Substancialista no STF. Revista Direito e Práxis, Rio de Janeiro, vol. 7, n. 1, p. 346-388, 2016.

CAPPELLETTI, Mauro. $\mathbf{O}$ controle de constitucionalidade no direito comparado. Trad. de Aroldo Plínio Gonçalves. Porto Alegre, 1984.

CHEIBUB, José Antônio; FIGUEIREDO, Argelina Cheibub; LIMONGI, Fernando. Partidos Políticos e Governadores como determinantes do comportamento legislativo na Câmara dos Deputados. Revista de Ciências Sociais, Rio de Janeiro, v. 52, n. 2, p. 263-299, 2009.

DWORKIN, Ronald. Freedom's Law: the moral reading of the American Constitution. New York: Oxford University Press, 1996. 
ELY, John Hart. Democracia e desconfiança: uma teoria do controle judicial de constitucionalidade. Trad. de Juliana Lemos. São Paulo: Martins Fontes, 2010.

FIGUEIREDO, Argelina Cheibub; LIMONGI, Fernando. Instituições Políticas e Governabilidade: Desempenho do governo e apoio legislativo da democracia brasileira. In: Carlos Ranulfo Melo; Manuel Alcântara Sáez. (Org.). A Democracia Brasileira: Balanço e perspectivas para o Século 21. Belo Horizonte: UFMG, 2007.

KLARMAN, Michael J. How Brown changed race relations: the backlash thesis. The Journal of American History, Oxford, vol. 81, n. 1, p. 81-118, jun. 1994.

LOEWENSTEIN, Karl. Teoría de la constitutión. 2. ed. Barcelona: Ariel, 1976.

MENDES, Conrado Hübner. Direitos fundamentais, separação de poderes e deliberação. São Paulo: Saraiva, 2011.

MORAIS, Fausto Santos de. Ponderação e arbitrariedade: a inadequada recepção de Alexy pelo STF. Salvador: Juspodivm, 2016.

MORAIS, Fausto Santos de; DOS SANTOS, José Paulo Schneider. Democracia às escuras?. Empório do direito. Disponível em: <http://emporiododireito.com.br/democracia-as-escuras-por-fausto-santos-de-morais-e-jose-paulo-schneider-dos-santos/>. Acesso em 26 out. 2015.

POST, Robert C.; SIEGEL Reva B. Roe Rage: Democratic constitutionalism and backlash. Harvard Civil Rights-Civil Liberties Law Review, Cambridge, vol. 42, n. 2, p. 373-433, 2007.

REIS, Márlon. Eleições proporcionais em dois turnos: um sistema eleitoral para o país. In: ARANTES, Aldo Silva (Org.). A OAB e a reforma política democrática. Brasília: OAB, 2014, p. 39-50.

ROESLER, Claudia Rosane. Entre o paroxismo de razões e a razão nenhuma: paradoxos de uma prática juridical. Revista de Direito da Universidade de Brasília, Brasília, vol. 2, n. 1, p. 79-95, 2016.

SILVA, Virgílio Afonso da. "Um voto qualquer"? O papel do Ministro Relator na deliberação no Supremo Tribunal Federal. Revista Estudos Institucionais, Rio de Janeiro, vol. 1, n. 1, p. 180-200, jul./dez. 2015.

SILVA, Virgílio Afonso da. Deciding without deliberating. International Journal of Constitutional Law, Oxford, vol. 11, n. 3, p. 557-584, jul./sept. 2013.

SILVA, Virgílio Afonso da. O STF e o controle de constitucionalidade: deliberação, diálogo e razão pública. Revista de Direito Administrativo, Rio de Janeiro, vol. 250, p. 197-227, 2009.

STRECK, Lenio Luiz. Hermenêutica jurídica em crise: uma exploração hermenêutica da construção do Direito. 11. ed. rev., atual. e ampl. Porto Alegre: Livraria do Advogado, 2014.

STRECK, Lenio Luiz. Jurisdição constitucional e decisão jurídica. 4. ed. São Paulo: Editora Revista dos Tribunais, 2014. 
STRECK, Lenio Luiz. Os Dilemas da Representação Política: O Estado Constitucional entre a Democracia e o Presidencialismo de Coalizão. Direito, Estado e Sociedade, Rio de Janeiro, n. 44, p. 83-101, jan./jun. 2014.

SUNSTEIN, Cass. A Constitution of many minds: why the founding document doesn't mean what it meant before. New Jersey: Princeton University Press, 2009.

TUSHNET, Mark. New institutional mechanisms for making constitutional law. In: BUSTAMANTE, Thomas; FERNANDES, Bernardo Gonçalves (Orgs.). Democratizing constitutional law: perspectives on legal theory and the legitimacy of constitutionalism. Heidelberg: Springer, 2016, p. 179-183.

VIEIRA, Oscar Vilhena. Supremocracia. Revista Direito GV, São Paulo, vol. 4, n. 2, p. 445-463, jul./ dez. 2008.

WALDRON, Jeremy. A dignidade da legislação. Trad. de Luís Carlos Borges. São Paulo: Martins Fontes, 2003.

WALDRON, Jeremy. Judges as moral reasoners. International Journal of Constitutional Law (I-CON), Oxford, vol. 7, n. 1, p. 2-24, 2009.

WALDRON, Jeremy. Judicial Review and Judicial Supremacy. Public Law and Legal Theory Research, New York, p. 14-57, 2014. Disponível em: <http://ssrn.com/abstract=2510550>. Acesso em: 12 nov. 2015.

WALDRON, Jeremy. Law and disagreement. New York: Oxford University Press, 1999.

WALDRON, Jeremy. Legislating with Integrity. Fordham Law Review, New York, vol. 72, n. 2 p. 373-394, 2003.

WALDRON, Jeremy. Parliamentary recklessness: why we need to legislate more carefully. Maxim Institute. Auckland: New Zealand, 2008.

WALDRON, Jeremy. Political political theory: essays on institutions. Cambridge: Harvard Univeristy Press, 2016.

WALDRON, Jeremy. Refining the question about judges' moral capacity. International Journal of Constitutional Law (I-CON), Oxford vol. 7, n. 1, p. 69-82, 2009.

WALDRON, Jeremy. The core case against judicial review. The Yale Law Journal, New Haven vol. 115, n. 6, p. 1346-1406, apr. 2006. 